\title{
INDONESIA ZERO EMISSIONS APPLICATION (EMISI): METHODOLOGIES FOR CALCULATING URBAN TRANSPORT EMISSIONS AND TREE SEQUESTRATION
}

\author{
MUHAMAD RIZKI, DEWI SARI, NANDA NOOR, IMAM BASUKI, RINALDI IMANUDDIN, SENY DAMAYANTI, \\ AND NADIA IRWANTO
}

\section{EXECUTIVE SUMMARY}

In recent decades, greenhouse gases (GHGs) and air pollutant emissions have increased due to land transport activities. This substantial growth has accelerated climate change and the deterioration of urban air quality, which have intensified serious hazards and have increased public health risks. Therefore, significant environmental action is urgently needed to mitigate the impact of climate change and air pollution on both the environment and human life. Globally, however, Indonesia has one of the largest populations of climate change deniers. Hence, it is crucial to establish a locally relevant platform - using Indonesia's emissions factors and profiles-that can educate and empower Indonesians to take action to mitigate their transportation impact on climate change. Therefore, the Indonesia Zero Emissions Application (EMISI) was developed to help users easily calculate and learn how to sequester their GHGs emissions, starting with urban commuting and transport activities.

This Technical Note describes the method within EMISI for calculating individual-level GHGs and air pollutant emissions from urban transport activities and then determining the necessary carbon sequestration through reforestation and afforestation. The application uses the bottom-up approach to calculate carbon dioxide, sulfur dioxide, carbon monoxide, fine particulate matter, and nitrogen oxides emissions to make them personal, science driven, and trackable; this helps users understand how their travel activities contribute to GHGs and air pollutant emissions. For emissions sequestration, EMISI uses guidelines and methodologies adopted from the Intergovernmental Panel on Climate Change and the Clean Development Mechanism. This shows users how they can sequester their GHGs emissions by planting trees; it also provides the required number of trees for a specific species planted in a specific location.

\section{CONTENTS}

Executive Summary ....................................... 1

Introduction .................................................

Methods ......................................................

Limitations.................................................14

Appendix A: Examples of GHG and Air Pollutant

Emissions Calculations.....................................15

Appendix B: Sequestered $\mathrm{CO}_{2}$ Calculation Details Using

Five Approaches .......................................18

Appendix C: Number of Trees Calculated from Total

Emissions per Person ....................................... 23

Abbreviations ........................................... 24

References .............................................. 25

Acknowledgments...................................... 28

About the Authors ......................................... 28

About WRI ............................................ 28

WRI Technical Notes document methodology underpinning research publications, interactive applications, and other tools.

Suggested Citation: M. Rizki, D. Sari, N. Noor, I. Basuki, R. Imanuddin, S. Damayanti, N. Irwanto. 2020. "Indonesia Zero Emissions Application (EMISI): Methodologies for Calculating Urban Transport Emissions and Tree Sequestration.” Technical Note. Jakarta, Indonesia: WRI Indonesia. Available online at www.wri-indonesia.org/en/publication/technical-note-emisiapp-urban-transport-tree. 
This methodology could be adopted by various stakeholders in Indonesia-including government, nongovernmental and private organizations, communities, scientific experts, and the general publichelping them to embed it in their systems, develop their own calculators, and improve Indonesia's carbon sequestration knowledge as well as add value to other research and development purposes. Despite utilizing the best available data and models, the methodologies in this Technical Note have several limitations and room for future improvement.

\section{INTRODUCTION}

Rapid motorization, low public transport use, excessive travel, and massive congestion are among the main reasons why the transport sector has become one of the major producers of emissions and air pollution in Indonesia (Erou and Fadillah 2019; World Bank 2019). The proportion of total emissions from land transport sectors increased from 9 percent in 2010 to 12 percent in 2017 (MoEF 2019). Meanwhile, Indonesia has the highest percentage of climate change deniers among 23 nations, with 18 percent of its population still not convinced that human behavior plays a role in climate change (Hilman and Harvey 2019). This indicates that public understanding and responses to climate change issues are still limited in Indonesia. Failing to act on these issues will cause an irreversible chain reaction that results in ecosystem losses, food security risks, economic losses, and other potential disasters. At the same time, the increasing air pollution from urban commuting in Indonesian cities also leads to serious public health risks as well as declining productivity (Amalia et al. 2013). Thus, it is important to instill the Indonesian people with a stronger awareness of their transportation impact on the climate crisis and the sustainability of cities as well as to provide them with opportunities to conduct wider climate action.

Around the world, various government agencies and multinational companies have implemented programs to increase public awareness about transport emissions. These programs have used statistical measurements to personalize individual-level emissions. For instance, the Energy Efficiency and Conservation Authority of New Zealand developed a carbon dioxide $\left(\mathrm{CO}_{2}\right)$ emissions calculator for transport by using fuel consumption and fuel type data (EECA 2019). The International Civil Aviation Organization and Scandinavian Airlines
System also built a $\mathrm{CO}_{2}$ calculator for air transport (ICAO 2016; SAS 2019). Most of these existing calculators are relevant for developed countries, but none reflects developing countries, specifically Indonesia. A proper Indonesia-specific emissions calculator would add value to relevant Indonesian environmental policies by considering the country's unique sociodemographic and economic characteristics and its scientific numbers (e.g., emissions factors) (Brander et al. 2011; Hasan et al. 2012; MoEF 2010).

Therefore, the Indonesia Zero Emissions Application (EMISI) was developed to fill that gap, providing an easy-to-access educational tool for Indonesians to calculate their emissions and learn about their carbon footprint and its impact on their environment and communities. EMISI is mainly a mobile application because cell phones are one of the most accessible device types for Indonesians. As a result, it can facilitate a direct, quick call to action. As a platform, EMISI enables more individuals to track their personal emissions and then act to reduce them. The application also promotes carbon sequestration as a last resort, allowing users to calculate the total number of trees that would need to be planted. Although EMISI comprehensively provides the tools and mechanism of the calculation, reduction, and sequestration of an individual's transport emissions, this Technical Note specifically explains the scientific methodologies for all calculations in the application. The analysis follows the bottom-up approach used by the Intergovernmental Panel on Climate Change (IPCC) to calculate greenhouse gas (GHG) and air pollutant emissions (IPCC 2006). To calculate the emissions sequestration, EMISI uses the Clean Development Mechanism (CDM) methodology booklet (UNFCCC 2019) and the IPCC guideline (Aalde et al. 2006) for $\mathrm{CO}_{2}$ removal.

This Technical Note focuses on calculating $\mathrm{CO}_{2}$ as GHG emissions and carbon monoxide (CO), nitrogen oxides $\left(\mathrm{NO}_{\mathrm{x}}\right)$, fine particulate matter $\left(\mathrm{PM}_{2.5}\right)$, and sulfur dioxide $\left(\mathrm{SO}_{2}\right)$ as air pollutants, considering their substantial implication to climate change and air pollution. To make the solutions more locally relevant, reforestation (including afforestation and forest restoration) was chosen from various alternatives for sequestering $\mathrm{CO}_{2}$ emissions because it is one of the most accessible and cost-efficient $\mathrm{CO}_{2}$ removal strategies in Indonesia (Graham et al. 2016, 2017). Hence, the sequestration calculation in this Technical Note focuses on reforestation and 
analyzes a limited number of tree species and locations in Indonesia that have ongoing tree-planting activities. The tree biomass (aboveground and belowground) used in the sequestration estimation is based on Indonesia's best available data, latest possible model, and assumptions provided in national and international scientific publications. By including this calculation, EMISI also aims to help Indonesia integrate and enhance its citizens' individual tree emissions sequestration data for further research and development purposes.

\section{METHODS}

The method used in EMISI is designated to equip the application with accountable, Indonesia-specific emissions and sequestration calculations for the urban commuter sector; these calculations are generated from various national and international studies. This method consists of four parts, as illustrated in Figure 1: flow of user data input for travel characteristics, the GHG and air pollutant emissions calculation, data input for tree planting, and the tree-based sequestration calculation.

For the first part, which consists of input data for all transport emissions calculations, users need to input their travel characteristics, such as transport modes, trip frequency, and the number of people traveling together on private transport (i.e., car or motorcycle) and taxi (including car-based ride-hailing) modes. The transport modes provided in EMISI correspond to the actual available modes in Indonesian cities. Although private transport and public transport (i.e., bus and rail transit) are commonly used in various emissions calculators, EMISI also provides paratransit as one of the common transport modes in Indonesian cities (Joewono and Kubota 2007). The users' travel distance is generated using Google Maps application that is included in EMISI's programming, in which users input their journey's origin and destination.

The second part uses fuel-based and distance-based methods to calculate GHG and air pollutant emissions (Brander et al. 2011). These methods are based on literature about transport emissions calculations (Brander et al. 2011; IPCC 2006; Wang and Rakha 2017; Zadek and Schulz 2010) and consider Indonesian emissions factors (EFs) and fuel economy (Boedisantoso et al. 2019; Hasan et al. 2012; MoEF 2010, 2017; MoEMR 2017).
The third part collects user input data to determine their tree-planting activities. EMISI considers tree species and locations or ecosystems that are relevant to Indonesia's landscape and will be feasible for reforestation activities and sequestration calculations. Only $\mathrm{CO}_{2}$ emissions are included in the sequestration calculation, following the natural ability of trees to sequester $\mathrm{CO}_{2}$ by converting it into biomass.

The fourth and last part shows the tree-based carbon sequestration calculation to define the quantity and type of trees needed to sequester the user's $\mathrm{CO}_{2}$ emissions from urban commuting. This part estimates the amount of $\mathrm{CO}_{2}$ that can be removed by planting different types of trees. Using methods and factors generated by the IPCC guidelines and CDM methodology, EMISI can suggest both the species and number of trees that would need to be planted (Gorte 2009; Krisnawati et al. 2012). 
Figure 1 | The EMISI Method Framework
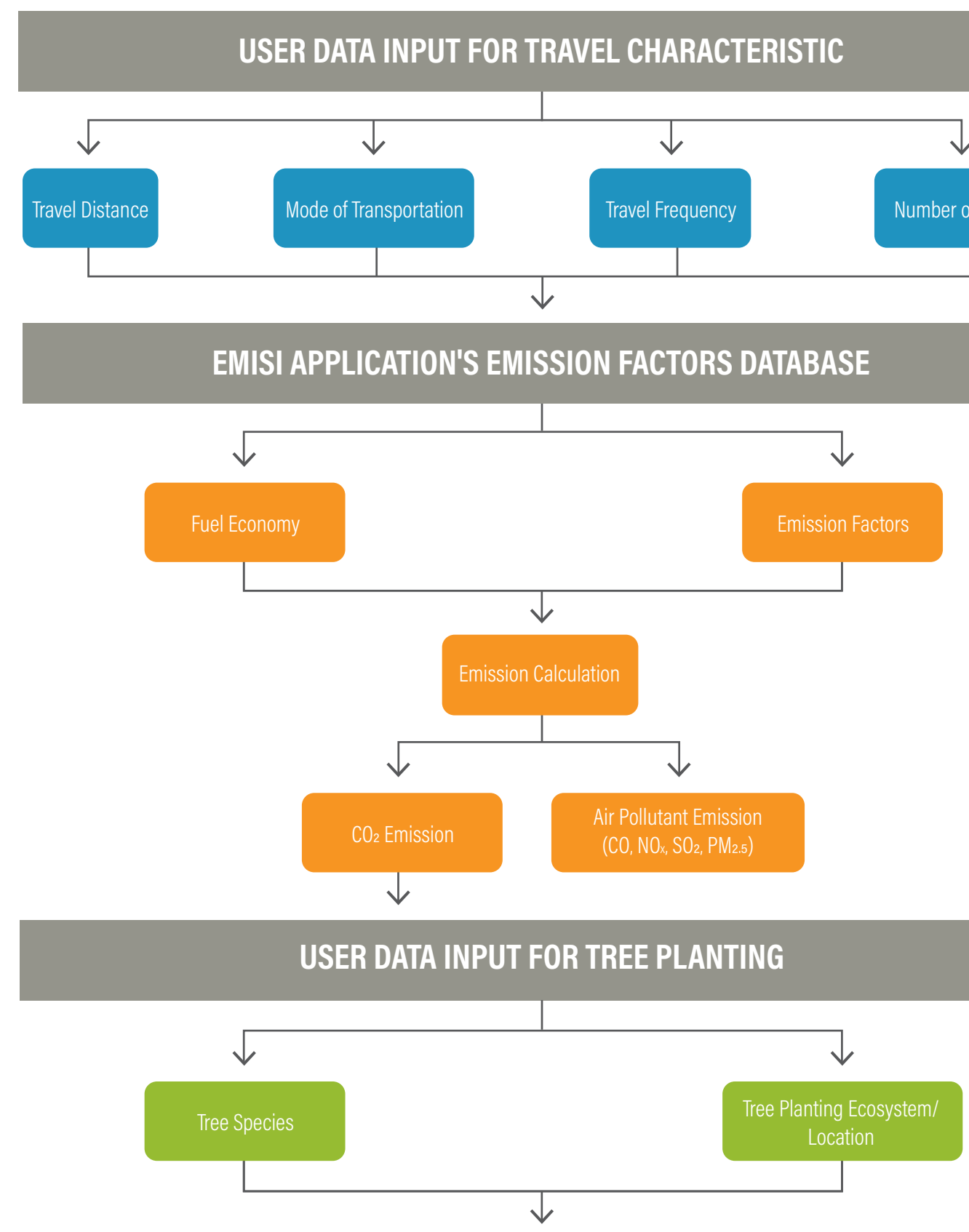

\section{EMISI APPLICATION'S TREE SEQUESTRATION FACTORS DATABASE}

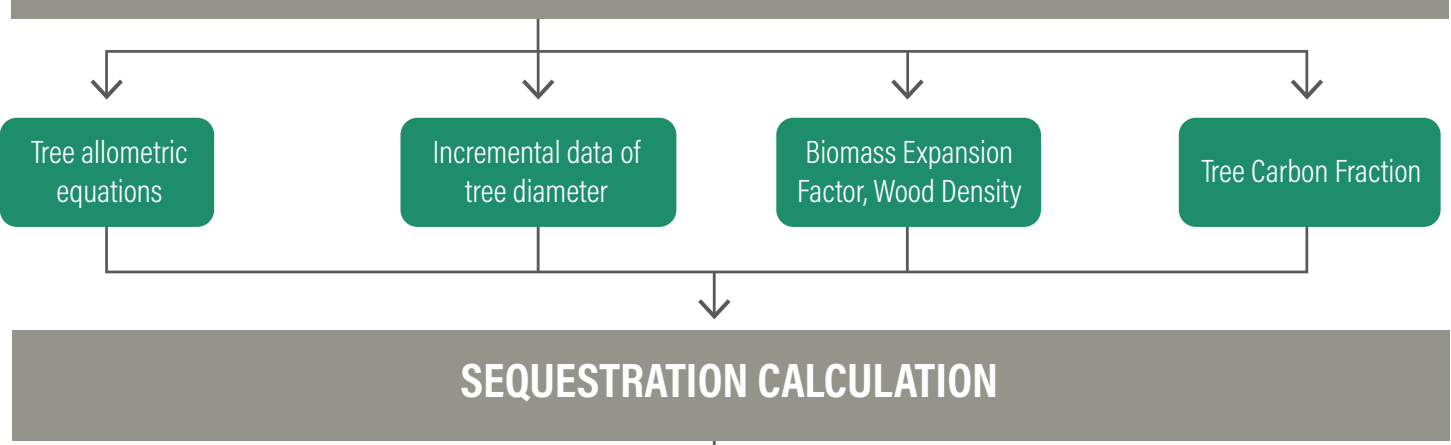




\section{Calculating Transport Activity Emissions}

The Method for Calculating GHG and Air Pollutant Emissions

The IPCC's Guidelines for National Greenhouse Gas Inventories (2006) classifies transport activities as mobile sources of emissions. The guidelines categorize the emissions calculation methodology as either top-down or bottom-up (Song 2017; van Vuuren et al. 2009). As recommended by the IPCC (2006), which prefers an activity-based calculation, and while also considering that EMISI will gather data about individual citizens' travel characteristics, this Technical Note uses the bottom-up approach to calculate emissions.

The bottom-up approach can be calculated by using the fuel-based or the distance-based method (Zadek and Schulz 2010), and both methods use EFs to calculate GHG $\left(\mathrm{CO}_{2}\right)$ and air pollutant $\left(\mathrm{CO}, \mathrm{NO}_{\mathrm{x}}, \mathrm{PM}_{2.5}\right.$, and $\left.\mathrm{SO}_{2}\right)$ emissions. These factors express the calculated ratio between GHG and air pollutant emissions and activity data (i.e., fuel consumption and distance traveled). The distance-based method simply multiplies the distance traveled by an emissions factor, but the fuel-based method uses a two-step calculation. It begins by converting the distance traveled to energy consumption by multiplying it by the energy economy factors. The total emissions, then, are produced by multiplying the energy consumption by the EFs.

The formula for the fuel-based method to calculate GHG and air pollutant emissions is as follows:

Total emissions per person $\left(\operatorname{TEP}_{p}\right)=\sum_{i=1}^{N} \frac{D_{i}}{F C F_{i j}} x \frac{E F s_{k}}{P T_{i}}$ (1)

where $i(i=1,2, \ldots \mathrm{N})$ is the number of trips $\left(i^{\text {th }}\right)$ captured; $D_{i}$ is the total distance (kilometers) for the $i^{\text {th }}$ trip; $F C F_{i j}$ is the fuel economy factor for the transport mode $(j)$ on the $i^{\text {th }}$ trip in the units of kilometers per energy (i.e., liter or kilowatt-hour); $E F s_{k}$ is the $\mathrm{EF}$ based on the type of fuel (k) or power plant/grid (w) in the units of kilogram-emissions per energy (i.e., liter or kilowatt-hour); and $P T_{i}$ is the number of people traveling together on the $i^{\text {th }}$ trip. The total emissions per person is the sum of the emissions calculated throughout the trip.
Below is the formula for the distance-based method to calculate air pollutant emissions:

$$
\text { Total emissions per person }\left(T E P_{p}\right)=\sum_{i=1}^{N} \frac{D_{i} x E F s_{j}}{P T_{i}} \text { (2) }
$$

where $i(i=1,2, \ldots N)$ is the number of trips $\left(i^{\text {th }}\right)$ captured; $D_{i}$ is the total distance (kilometers) for the $i^{\text {th }}$ trip; $E F s_{j}$ is the EF based on the transport mode ( $j$ ) in the units of kilogram-emissions per kilometer; and $P T_{i}$ is the number of people traveling together on the $i^{\text {th }}$ trip. The total emissions per person is the sum of the emissions calculated throughout the trip.

\section{The Determinants for Calculating GHG Emissions}

To calculate the GHG $\left(\mathrm{CO}_{2}\right)$ emissions, the fuel-based method requires the energy consumption for every trip that users inputted into EMISI. Although users only inputted their trips' origin and destination-and then Google Maps generated the distance traveled-energy consumption is calculated by dividing the distance traveled by the energy economy factor. The energy economy factor for land transport is based on the type of transport mode (i.e., car, motorcycle, bus), as suggested by the IPCC (2006), and also on the national average number provided by Indonesia's Ministry of Environment and Forestry (MoEF) (2010). Specific energy economy factors for urban rail are derived from a study conducted by Wang and Rakha (2017) that modeled electricity consumption factors for urban rail in the United States based on the number of train cars per set (six and eight cars). The summary of such energy economy factors is provided in Table 1. 
Table 1 | Energy Economy Factors

\begin{tabular}{|c|c|c|}
\hline TRANSPORT MODES & ENERGY ECONOMY FACTORS & UNIT \\
\hline Car (gasoline) ${ }^{\mathrm{a}}$ & 9.8 & $\mathrm{~km} / \mathrm{liter}$ \\
\hline Van/minibus (gasoline) ${ }^{a}$ & 8 & $\mathrm{~km} / \mathrm{liter}$ \\
\hline Car (diesel) $)^{b}$ & 10.3 & $\mathrm{~km} / \mathrm{liter}$ \\
\hline Paratransit (gasoline) ${ }^{\mathrm{a}}$ & 7.5 & $\mathrm{~km} / \mathrm{liter}$ \\
\hline Taxi (gasoline)a & 8.7 & $\mathrm{~km} / \mathrm{liter}$ \\
\hline Medium bus (diesel) ${ }^{\mathrm{a}}$ & 4.0 & $\mathrm{~km} / \mathrm{liter}$ \\
\hline Big bus (diesel)a & 3.5 & $\mathrm{~km} / \mathrm{liter}$ \\
\hline Motorcycle (gasoline) ${ }^{\mathrm{a}}$ & 28 & $\mathrm{~km} / \mathrm{liter}$ \\
\hline Electric urban rail $(8 \text { cars })^{c}$ & 0.0325 & $\mathrm{~km} / \mathrm{kWh}$ \\
\hline Electric urban rail $(6 \text { cars })^{c}$ & 0.0433 & $\mathrm{~km} / \mathrm{kWh}$ \\
\hline
\end{tabular}

Note: $\mathrm{kWh}=$ kilowatt-hour.

Sources: a. MoEF 2010; b. IPCC 2006; c. Wang and Rakha 2017.

The calculated energy consumption is then multiplied by the EFs that corresponds to each fuel/energy type, as described in Table 2. Like the fuel consumption, EFs for $\mathrm{CO}_{2}$ are based on fossil fuel consumption and electricity production. In particular, the fossil fuel EFs resulted from conversions, by multiplying EFs from MoEF (2017) and the Ministry of Energy and Mineral Resources
(2017) local reference, in unit $\mathrm{kg} \mathrm{CO}_{2}$ /terajoules with their heating value (TJ/liter). Meanwhile, the EFs for the electricity consumption of urban rail transit use Indonesian standards of electrical EFs for grid electricity by Brander et al. (2011).

Table 2 | $\mathrm{CO}_{2}$ Emissions Factors

\begin{tabular}{|l|l|l|}
\hline FUEL/ENERGY & $\mathbf{C O}_{2}$ EMISSIONS FACTOR & UNIT \\
\hline Automotive diesel oil a,b & 2.68 & $\mathrm{~kg} \mathrm{CO}_{2} / \mathrm{liter}$ \\
\hline RON 92 gasoline ${ }^{a, b}$ & 2.39 & $\mathrm{~kg} \mathrm{CO}_{2} / \mathrm{liter}$ \\
\hline RON 88 gasoline ${ }^{a, b}$ & 2.41 & $\mathrm{~kg} \mathrm{CO}_{2} / \mathrm{liter}$ \\
\hline Grid electricity ${ }^{c}$ & 0.774 & $\mathrm{~kg} \mathrm{CO}_{2} / \mathrm{kWh}$
\end{tabular}

Notes: $\mathrm{kWh}=$ kilowatt-hour. The heating value for gasoline is $33 \times 10^{-6}$ terajoules/liter; for diesel it is $38 \times 10^{-6}$ terajoules/liter (MoEF 2012).

Sources: a. MoEF 2010; b. MoEMR 2017; c. Brander et al. 2011. 


\section{The Determinants for Calculating Air Pollutant} Emissions

To calculate the air pollutant $\left(\mathrm{CO}, \mathrm{NO}_{\mathrm{x}}, \mathrm{PM}_{2.5}\right.$, and $\left.\mathrm{SO}_{2}\right)$ emissions, the distance-based method is used for all trips except those involving urban rail, which uses the fuel-based method. The required data is similar to the $\mathrm{CO}_{2}$ emissions calculation method, although EFs used for calculating air pollutant emissions are based on the distance traveled and the mode of transport. The EFs for air pollutants are obtained from studies conducted by the MoEF (2010) and Boedisantoso et al. (2019), as shown in Table 3. The EFs from electricity are sourced from Hasan et al. (2012), who distinguish air pollutant EFs based on the type of fuel used in power plants in Indonesia. The EFs for $\mathrm{PM}_{2.5}$ are sourced from Shrestha et al. (2013), who developed the Atmospheric Brown Clouds (ABC): Emission Inventory Manual for Asian cities.

To simplify the calculation, the following factors were excluded from the analysis because they would not have significantly changed the calculation results:

Driving behavior in various conditions

(i.e., congestion or free flowing)
Vehicle engine maintenance as well as years of use after vehicle production

It is assumed that these factors had already been considered when the EFs or energy economy factors were produced. Moreover, to calculate GHG and air pollutant emissions per person for paratransit, bus, and urban rail modes, the number of passengers based on the existing capacity and load factor are simplified using the following assumptions:

The load factor for all modes is assumed to be about 70 percent of its capacity.

For paratransit and bus modes, the capacity is 14 and 73 people per vehicle, respectively, according to a study by Cervero (1991) and Trans Jakarta (Jakarta Bus Management Company) (Ghozali 2018).

The urban rail capacity is 250 people per car, with a total of eight cars per train set, according to the Indonesian Commuter Rail Company (commuter railway operator) (Rudi 2015).

Table 3 | Air Pollutant Emissions Factors

\begin{tabular}{|c|c|c|c|c|}
\hline \multirow{2}{*}{$\begin{array}{l}\text { VEHICLE TYPE / MODE } \\
\text { OF TRANSPORT }\end{array}$} & \multicolumn{4}{|c|}{ EMISSIONS FACTORS } \\
\hline & KG CO/KM & KG NOx/KM & KG PM $2.5 / K M$ & $\mathrm{KGSO} / \mathrm{KM}$ \\
\hline Motorcycle ${ }^{a, b, c}$ & 0.0140 & 0.00029 & 0.000032 & 0.000008 \\
\hline Car (gasoline) ${ }^{a, b, c}$ & 0.0400 & 0.0020 & 0.00005 & 0.000026 \\
\hline Car (diesel) ${ }^{a, b, c}$ & 0.0028 & 0.0035 & 0.00084 & 0.00044 \\
\hline Paratransit ${ }^{a, b, c}$ & 0.0431 & 0.0021 & 0.00006 & 0.000029 \\
\hline$B u s^{a, b, c}$ & 0.0110 & 0.0119 & 0.00042 & 0.00093 \\
\hline $\begin{array}{l}\text { ELECTRICITY EMISSIONS } \\
\text { FACTOR BASED ON } \\
\text { POWER PLANT }\end{array}$ & KG CO/KWH & KG NOx/KWH & KG PM $2.5 / K W H$ & $\mathrm{KG} \mathrm{SO}_{2} / \mathrm{KWH}$ \\
\hline Coall, d & 0.0002 & 0.0052 & 0.000189 & 0.0139 \\
\hline Natural gas ${ }^{c, d}$ & 0.0005 & 0.0009 & 0.000140 & 0.0005 \\
\hline Fuel oil ${ }^{c, d}$ & 0.0002 & 0.0025 & 0.000055 & 0.0164 \\
\hline
\end{tabular}

Notes: $\mathrm{CO}$ = carbon monoxide; $\mathrm{kWh}$ = kilowatt-hour; $\mathrm{NO}$ = nitrogen oxides; $\mathrm{PM}_{2.5}$ = fine particulate matter; The heating value for gasoline is $33 \times 10^{-6}$ terajoules/liter; 
Furthermore, users also input their travel frequency in weekly units (trip/week). Therefore, assuming a month consistently consists of four weeks, to calculate the total emissions per person during a one-month period $(T E P-M), T E P p$ is multiplied by the total weekly frequency and number of weeks in a month that the trips are taken. Furthermore, given the fact that a year always consists of twelve months, to calculate the total emissions per person during a one-year period $\left(T E P_{p}-Y\right), T E P p-M$ is multiplied by the number of months in the year when the trips are taken. To provide a more practical illustration, examples of these emissions calculations are provided in Appendix A. The appendix presents three cases involving different travel characteristics and modes that consider locally relevant trip chains that Indonesians perform during their daily travels. The first case illustrates a comparison of people using motorcycles for ride-hailing services and cars in their daily trip chain. The second case illustrates the trip chain using a combination of car and urban rail, and the third case illustrates the trip chain using a combination of motorcycle and bus.

The framework for calculating emissions described in this section has a wide range of applications, as suggested by the CDM methodology (UNFCCC 2019). Whereas some studies investigate emissions reduction for various public transport projects (ADB 2017; Yuan and Frey 2020), others estimate the impact of improved technologies for reducing emissions (Xylia et al. 2019) and the impact of new mobility services, such as car sharing and ride hailing, on the production of emissions (Jung and Koo 2018; Suatmadi et al. 2019). Therefore, this Indonesia-specific framework can provide a practical emissions-tracking methodology that can be adapted to platforms by various stakeholders in Indonesia, including government, nongovernmental and private organizations, and communities.

\section{Calculating Emissions Sequestration}

Among other measures, tree planting has been widely promoted as an effort to effectively remove atmospheric $\mathrm{CO}_{2}$ to minimize the catastrophic effects of climate change (Buis 2019; Carrington 2019; Coppolino 2014; Rathi 2020). Besides $\mathrm{CO}_{2}$, studies also found that trees can absorb air pollutants, but only physical interaction influences the dispersion and deposition of air pollutants, and the trees should be planted close to the source of pollution (Badach et al. 2020; Janhäll 2015). However, planting activities in EMISI are conducted in various locations and are not necessarily at the location where emissions were released. Therefore, tree-planting activities may not be an appropriate approach to sequester air pollutants, which will not be converted to $\mathrm{CO}_{2}$ equivalents. Thus, this method only considers sequestration of $\mathrm{CO}_{2}$.

The scale and purpose of the sequestration efforts vary from individual to large-scale tree planting and from reforestation to afforestation (Bäckstrand and Lövbrand 2006; Gorte 2009). EMISI estimates the number of planted trees based on total $\mathrm{CO}_{2}$ emitted per user, calculated as follows:

Number of trees $=\frac{\mathrm{TEP}_{p} \mathrm{CO}_{2}}{\text { Estimated sequestered } \mathrm{CO}_{2} \text { per tree }}(3)$

where $\mathrm{TEP}_{\mathrm{p}} \mathrm{CO}_{2}$ refers to Equation 1, and estimated sequestered $\mathrm{CO}_{2}$ (ESC) per tree is influenced by growth rate (stem diameter and height increment) of the tree and the ecosystem performance to uptake $\mathrm{CO}_{2}$ (Röhling et al. 2016), which depends on tree species and ecosystem type (Bernal et al. 2018; Kirby and Potvin 2007). Tree species and ecosystem type of planting activities are important to achieve the optimum impact of tree planting for $\mathrm{CO}_{2}$ removal. Moreover, standardizing seedling quality, maintaining environmental condition, and nurturing treatment are three factors affecting the growth and survival rate of planted trees and, hence, their capacity to remove $\mathrm{CO}_{2}$ (Jaenicke 1999). Therefore, tree-planting activities within EMISI maintain these factors to reach optimum carbon sequestration capacity.

Carbon sequestration estimates can be calculated using the total change in several relevant carbon pools (namely, the stock difference method) or in carbon fluxes (the gain-loss method). The stock difference method considers carbon pools that include biomass (aboveground and belowground), dead organic matter (dead wood and litter), and soil organic matter. The gain-loss method uses a carbon input component (i.e., net primary production) and output components (heterotrophic respiration, methane and nitrous oxide emissions, fire and water flow emissions) (Basuki et al. 2019; Hergoualc'h and Verchot 2011). EMISI uses the stock difference method to estimate $\mathrm{CO}_{2}$ removal from tree-planting activities because it is considered a generic methodology that is applicable to multiple land-use categories (Aalde et al. 2006).

According to method AR-AMSooo7 of the United Nations Framework Convention on Climate Change (2019) regarding afforestation/reforestation on land other than wetlands, $\mathrm{CO}_{2}$ removal is achieved by increasing carbon stocks in the following pools: mainly aboveground (AGB) and belowground biomass (BGB), 


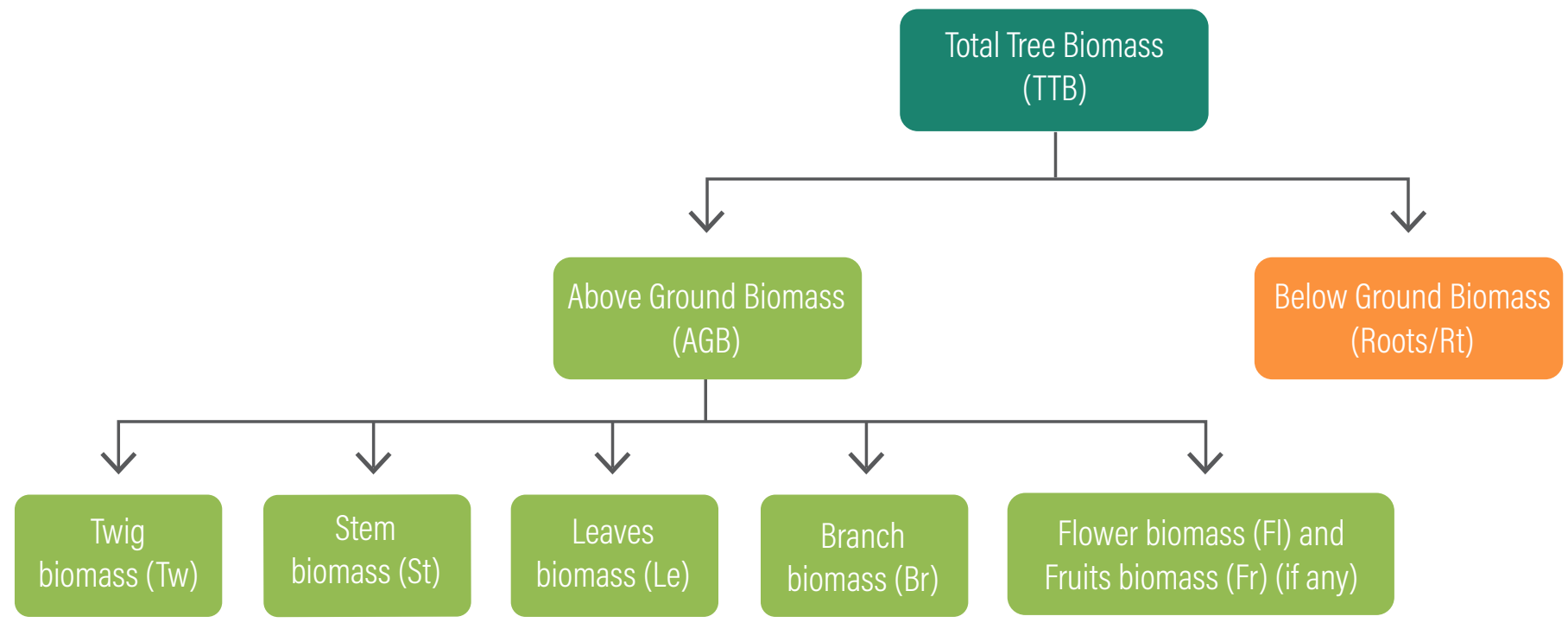

Source: WRI authors.

while deadwood, litter, and soil organic carbon are optional. Based on this, the calculation method used in EMISI will only consider AGB and BGB carbon pools in accordance with the CDM methodology booklet and the IPCC (Aalde et al. 2006). Changes in carbon stocks can be calculated using the global default value (Tier 1), nationally derived data (Tier 2), or the country-based methodology with specific equations/models in specific forest types (Tier 3) (Aalde et al. 2006).

EMISI aims to use the Tier 3 method using Indonesianbased tree allometric equations/models derived from locally relevant locations and ecosystems documented in Allometric Models for Estimating Tree Biomass at Various Forest Ecosystem Types in Indonesia (Krisnawati et al. 2012) and other recent literature about the Indonesian-based allometric model. Allometric equations estimate the biomass by correlating tree diameter and height with tree biomass components (Figure 2). The equations can also represent the function of diameter to total tree biomass (TTB) or the function of diameter to each component of tree biomass. In addition, the allometric equations can represent the function of diameter to tree volume (V), converted to biomass using wood density (WD), and the biomass expansion factor (BEF). Finally, the carbon stock is estimated by multiplying biomass with the carbon fraction coefficient.

However, allometric equations are not always available for all Indonesian tree species in specific ecosystems and locations. This is because developing species-specific allometric equations for Indonesia's highly diverse tropical forests is laborious, cost ineffective, and almost impossible (Paul et al. 2016). Tree-specific allometric equations also may produce errors and biases due to the small sample sizes, limited tree diameter ranges, and other factors that are not represented in the allometric, such as geographical, biophysical, and forest boundaries (Manuri et al. 2016). Therefore, some approaches have been developed to select the most suitable allometric equations according to defined standards, including the number of samples, the diameter ranges used to develop the allometric, the ecosystem type, and the location of tree samples. Consequently, carbon sequestration for some species might be calculated using a generic allometric equation for several ecosystem types in Indonesia because existing allometric equations do not meet the standard criteria. Examples of generic allometric equations include those developed by Chave et al. (2014) for tropical trees and Kusmana et al. (2018) for mangrove species.

The approaches used in this method have been adopted and modified from approaches developed by Krisnawati et al. (2012). Figure 3 illustrates the decision tree for selecting calculation approaches to estimate biomass based on the availability of a tree allometric that suits the defined criteria (number of samples and tree diameter ranges used to develop the allometric model). Five approaches are used in a consecutive order, from Approach 1 (most desirable) to Approach 5 (least desirable). 
Figure $3 \mid$ Decision Tree for Selecting Allometric Models to Estimate Tree Biomass

\section{Forest Inventory Data (Tree Species, Diameter [D], and Height [H])}

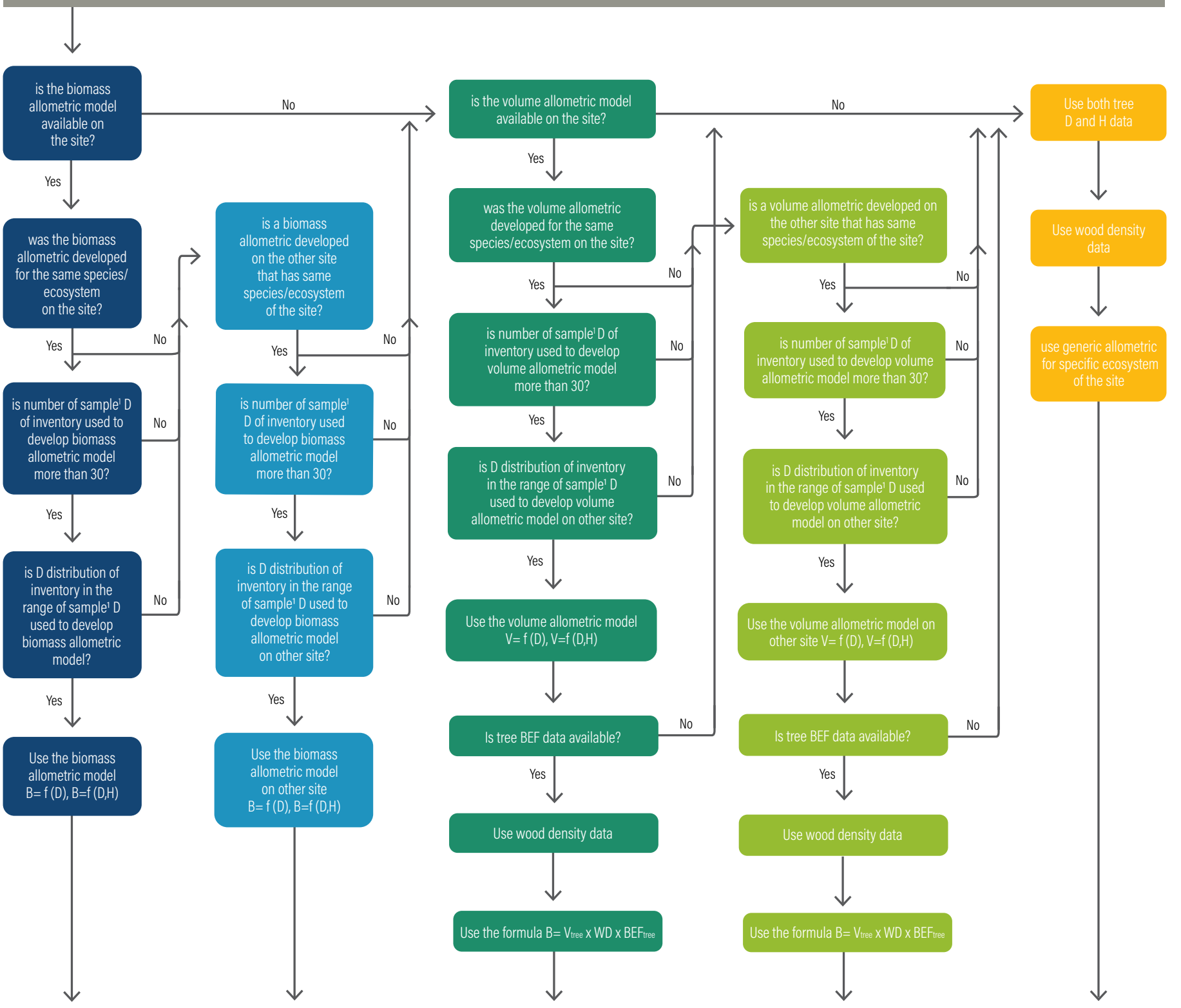

Above Ground Tree Biomass (kg)

\begin{tabular}{ll|l|l|l|l|l|l|l} 
Approach 1 & Approach 2 & Approach 3 & Approach 4 & Approach 5
\end{tabular}

Source: WRI authors. 
Approach 1 is used to estimate tree biomass using allometric models for specific species and ecosystems that are available in the tree-planting location. However, if a biomass allometric model is not available for the species and ecosystem in a tree-planting location, the model for another location with the same species and ecosystem can be used; this is called Approach 2. Next, Approach 3 is used to estimate tree biomass using the volume allometric model available for the specific species and ecosystem in the tree-planting location. Similar to Approach 2, if the volume allometric equation is not available for the tree-planting location, the equation for another location can be used; this is Approach 4. Lastly, Approach 5 uses generic allometric equations that are available for specific ecosystem types in the tree-planting locations.

EMISI quantifies the required number of trees based on the tree species, ecosystem, and location, considering the presence of reforestation and restoration activities implemented by Indonesian conservation and restoration organizations. Table 4 provides the potential list of species to be planted by several organizations across Indonesia. This list is not limited and can be expanded in the future. Tree species are based on the needs of the restoration area and the communities who live nearby; hence, some species are for agroforestry purposes.

Table 4 | List of Prospective Tree Species to Be Planted in Restoration Areas across Indonesia

\begin{tabular}{|c|c|c|c|}
\hline ECOSYSTEM TYPE & SPECIES & $\begin{array}{l}\text { INDONESIAN } \\
\text { COMMON NAME }\end{array}$ & $\begin{array}{l}\text { ENGLISH } \\
\text { COMMON NAME }\end{array}$ \\
\hline \multirow{4}{*}{ Secondary mangrove forest } & Avicennia marina & Bakau & White mangrove \\
\hline & Rhizopora apiculata & Bakau & Mangrove \\
\hline & Rhizopora mucronata & Bakau & Mangrove \\
\hline & Rhizopora stylosa & Bakau & Mangrove \\
\hline \multirow[t]{15}{*}{ Secondary dryland forest } & Aleurites moluccanus & Kemiri & Candle nut \\
\hline & Alstonia scholaris & Pala & Nutmeg \\
\hline & Archidendron pauciflorum & Jengkol & Stinky bean \\
\hline & Artocarpus integer & Cempedak & Jackfruit \\
\hline & Daemonorops draco & Jernang & Dragon's blood \\
\hline & Durio zibethinus & Durian & Durian \\
\hline & Eusideroxylon zwageri & Ulin/Bulian & Ulin \\
\hline & Gnetum gnemon & Melinjo & Gnemon \\
\hline & Lansium paraciticum & Langsat & Lanzones \\
\hline & Parkia speciosa & Petai & Bitter bean \\
\hline & Pinus merkussi & Pinus & Pine \\
\hline & Shorea senoptera Burck & Tengkawang & Tengkawang \\
\hline & Shorea spp. & Meranti & Meranti \\
\hline & Syzygium aromaticum & Cengkeh & Clove \\
\hline & Toona sureni & Surian & Surian \\
\hline
\end{tabular}

Source: WRI authors. 
Table 5 provides examples for calculating carbon sequestration for several species that can be planted through the EMISI application's tree-planting program. Besides the selected allometric model chosen based on the five approaches, the following assumptions are also applied to calculate tree-based carbon sequestration:

- Planted trees are assumed to survive for 20 years (the default time frame by the IPCC to estimate carbon stock from land-use change activities) and/or to reach a minimum of 10 centimeters $(\mathrm{cm})$ in diameter at the breast height (DBH).

Conservative scenarios estimate an annual increment of $0.5 \mathrm{~cm}$ stem diameter (Rexon and Pearson 2010) and 0.5 meters $(\mathrm{m})$ height $(\mathrm{H}) ; \mathrm{H}$ increments vary between 0.5 and $0.9 \mathrm{~m}$ during the first 20 years (Bustomi et al. 2009) for dryland trees or $0.1 \mathrm{~m}$ for mangrove trees (Siregar 2007).

The TTB is estimated using the allometric function (f) of stem diameter (D) to biomass for tree biomass components:

- $\mathrm{TTB}=\mathrm{f}(\mathrm{D})$ or TTB $=\mathrm{AGB}+\mathrm{BGB}$

- $\quad \mathrm{AGB}=\mathrm{f}(\mathrm{D})$

- $\quad \mathrm{BGB} /$ Roots $(\mathrm{Rt})=\mathrm{f}(\mathrm{D})$ or $\mathrm{BGB}=\mathrm{f}(\mathrm{AGB})$
Wood density (WD) for each tree species is the mean of WD data provided in the Tree Functional Attributes and Ecological Database. ${ }^{1}$

If the allometric equation for BGB/Rt is not available, the BGB is calculated using default shoot-root ratio (0.27), which is based on the 2006 IPCC guidelines.

If a tree carbon fraction is not available for a tree species or ecosystem, the default value of 0.47 is used based on the 2006 IPCC guidelines.

Table 5 also shows that the $\mathrm{CO}_{2}$ sequestration estimate falls between $5 \mathrm{O}$ and 150 kilograms $(\mathrm{kg})$ of $\mathrm{CO}_{2}$ per tree for five different tree species; the detailed total $\mathrm{CO}_{2}$ sequestration calculation can be found in Appendix B. The estimate for sequestered $\mathrm{CO}_{2}$ per tree is used to define the number of trees needed to sequester a user's travel-related emissions. Appendix $\mathrm{C}$ further illustrates the estimated number of trees needed per species to sequester different amounts of emissions in different cases. 
Table 5 | Parameters and Data Needed to Estimate Tree Species $\mathrm{CO}_{2}$ Sequestration Using Five Different Approaches

\begin{tabular}{|c|c|c|c|c|c|}
\hline \multirow{2}{*}{ PARAMETERS } & \multicolumn{5}{|c|}{ APPROACHES } \\
\hline & APPROACH 1 & APPROACH 2 & APPROACH 3 & APPROACH 4 & APPROACH 5 \\
\hline Tree species & Avicennia marina & Pinus merkussi & Eusideroxylon zwageri & Rhizopora apiculata & Artocarpus integer \\
\hline Tree diameter increment & $0.5 \mathrm{~cm}$ per year ${ }^{\mathrm{a}}$ & $0.5 \mathrm{~cm}$ per year ${ }^{\mathrm{a}}$ & $0.5 \mathrm{~cm}$ per year ${ }^{\mathrm{a}}$ & $0.5 \mathrm{~cm}$ per year ${ }^{\mathrm{a}}$ & $0.5 \mathrm{~cm}$ per year ${ }^{\mathrm{a}}$ \\
\hline Ecosystem & Mangrove forest & Dryland forest & Dryland forest & Mangrove forest & Dryland forest \\
\hline Location & West Java & Aceh & South Sumatra & DKI Jakarta & Aceh \\
\hline Allometric equation & $T T B=0.291 \times D^{2.260 b}$ & $\begin{array}{l}T T B=0.178 \times D^{2.586} \text { from } \\
\text { different location }{ }^{b}\end{array}$ & $V=0.000101 \times D^{2.619 b}$ & $\begin{array}{l}V=0.000107 \times D^{2.4} \text { from } \\
\text { different location }{ }^{b}\end{array}$ & $\begin{array}{l}A G B=0.0678 \\
\left(D^{2} \times W D \times H\right)^{0.976 d}\end{array}$ \\
\hline Number of samples & $47^{\mathrm{b}}$ & $80^{b}$ & $262^{b}$ & $50^{\mathrm{b}}$ & $>1000^{d}$ \\
\hline $\begin{array}{l}\text { Diameter range for } \\
\text { allometric equation }\end{array}$ & $6.4-35.2 \mathrm{~cm}^{b}$ & $0.4-44 \mathrm{~cm}^{\mathrm{b}}$ & $8-33 \mathrm{~cm}^{\mathrm{b}}$ & $10-57.6 \mathrm{~cm}^{\mathrm{b}}$ & $5-150 \mathrm{~cm}^{\mathrm{d}}$ \\
\hline $\begin{array}{l}\text { Biomass expansion factor } \\
\text { (BEF) }\end{array}$ & Not applicable & Not applicable & $1.49^{b}$ & $1.55^{b}$ & Not applicable \\
\hline Wood density (WD) & Not applicable & Not applicable & $561.2 \mathrm{~kg} / \mathrm{m}^{3 \mathrm{c}}$ & $583.6 \mathrm{~kg} / \mathrm{m}^{3 \mathrm{c}}$ & $647.6 \mathrm{~kg} / \mathrm{m}^{3 \mathrm{c}}$ \\
\hline Tree carbon fraction (TCF) & $0.47^{b}$ & $0.47^{\mathrm{b}}$ & $0.47^{b}$ & $0.47^{b}$ & $0.47^{b}$ \\
\hline Biomass calculation & TTB & TTB & $\begin{array}{l}A G B=V \times B E F \times W ; B G B= \\
T T B=A G B+B G B\end{array}$ & $0.27 \times A G B$ & $\begin{array}{l}B G B=0.27 \times A G B \\
T T B=A G B+B G B\end{array}$ \\
\hline Carbon stock calculation & & & Carbon stock $=T T B \times T$ & & \\
\hline $\mathrm{CO}_{2}$ calculation & & & $\mathrm{CO}_{2} \mathrm{e}=$ Carbon stock $\times$ & $\frac{44}{12}$ & \\
\hline $\begin{array}{l}\text { Estimated sequestered } \\
\mathrm{CO}_{2}(\mathrm{ESC}) \text { per tree }(\mathrm{kg})\end{array}$ & 91.3 & 51.1 & 146.8 & 94.1 & 100.1 \\
\hline $\begin{array}{l}\text { Average ESC per tree per } \\
\text { year }(\mathrm{kg})\end{array}$ & 4.6 & 2.5 & 7.3 & 4.7 & 5 \\
\hline
\end{tabular}

Notes: $\mathrm{AGB}=$ aboveground biomass; $\mathrm{BGB}=$ belowground biomass; $\mathrm{TTB}=$ total tree biomass.

Sources: a. Rexon and Pearson 2010; b. Krisnawati et al. 2012; c. Average WD is from the Tree Functional Attributes and Ecological Database, International Centre for Research in Agroforestry, http://db.worldagroforestry.org/; d. Chave et al. 2014.

'See the Tree Functional Attributes and Ecological Database, International Centre for Research in Agroforestry, http://db.worldagroforestry.org/. 


\section{LIMITATIONS}

Although EMISI educates and enables citizens to measure their transport-related GHG and air pollutant emissions along with the number of trees required for their sequestration, the method does have limitations. In developing countries, data availability has been a key barrier, as identified by Song (2017). The calculator focuses on developing the best estimates for Indonesian context; however, when local data are unavailable, the calculator uses data from global contexts to develop the next-best estimates. Recent and upcoming research data on the determinants for calculating emissions in Indonesia-specific cases, such as EFs and fuel consumption, will further improve future calculations. Therefore, these studies also encourage more detailed and localized data for those determinants due to demographic, economic, and infrastructure disparities across nations, affecting different behaviors and thus influencing the fuel consumption factor, among others.

The emissions sequestration calculation is estimated by using the best available tree allometric equation and tree increment prediction, which may contain errors and biases. The errors and biases are caused by several factors, including field measurement errors in producing allometric equations (Manuri et al. 2016). Another factor is that the allometric equation is limited in representing all factors that may affect the amount of tree biomass. For example, most local allometric equations only present correlations between tree diameter and biomass, which means other factors, such as tree height and age, are not represented. Moreover, the ability of trees to absorb $\mathrm{CO}_{2}$ and to grow may also be affected by seedling quality, environment, and treatment, which lead to some uncertainties that cannot be counted in the allometric equation and tree growth. Even though EMISI aims to standardize these factors, uncertainties may still exist. Furthermore, tree growth, which is presented as the annual increment of tree diameter and height, is assumed to have linear growth per year. On the ground, this may not be entirely true and may result in errors and biases that are not measured in the calculation method as well. However, such an assumption is still applicable because this method is acceptable for the $\mathrm{CO}_{2}$ removal calculation in the CDM methodology (Rexon and Pearson 2010). Another factor that can potentially lead to errors is the survival rate of trees; the EMISI application's tree-planting program reduces this factor by ensuring that all dying trees are replaced. This tree replacement process, however, may decrease the growth increment of the trees. Therefore, the assumption of tree growth is based on the lowest possible annual tree increment to compensate for the potential decline of tree increment due to tree replacement.

These potential errors and biases still cannot be defined directly in this calculation method due to unavailability of actual data for tree-planting activities. In the future, these potential errors and biases will be measured by comparing the projected and actual data to calculate the mean relative error, mean absolute relative error, and root mean square error. These error factors will then be used to further determine the best allometric equations and to improve the current allometric equation used for that specific tree species and planting location. 


\section{APPENDIX A: EXAMPLES OF GHG AND AIR POLLUTANT EMISSIONS CALCULATIONS}

Table A1 | Case 1: Using a Private Car or Motorcycle

\begin{tabular}{|c|c|c|c|c|c|c|c|c|c|}
\hline \multirow{5}{*}{ 更 } & 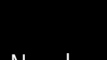 & \multirow[b]{2}{*}{$\begin{array}{l}\text { Modes of } \\
\text { transport }\end{array}$} & \multirow[b]{2}{*}{$\begin{array}{l}\text { Distance } \\
(\mathrm{km})\end{array}$} & \multirow{2}{*}{$\begin{array}{l}\text { Energy } \\
\text { conversion } \\
\text { (km/liter) }\end{array}$} & \multirow{2}{*}{\begin{tabular}{|l} 
Emissions factor \\
$\mathrm{CO}_{2}\left(\mathrm{kgCO}_{2} /\right.$ liter $)$
\end{tabular}} & \multirow{2}{*}{$\begin{array}{l}\text { Number } \\
\text { of people } \\
\text { traveling } \\
\text { together }\end{array}$} & \multirow{2}{*}{$\begin{array}{l}\text { Emissions per person } \\
\mathrm{kgCO}_{2} / \text { trip/person }\end{array}$} & \multirow{2}{*}{$\begin{array}{l}\text { Number of } \\
\text { trips per } \\
\text { month }\end{array}$} & \multirow{2}{*}{$\begin{array}{l}\text { Emissions per person } \\
\mathrm{kgCO}_{2} / \text { month/person }\end{array}$} \\
\hline & $\begin{array}{l}\text { Number } \\
\text { of trips }\end{array}$ & & & & & & & & \\
\hline & & (A) & (B) & (C) & (D) & $(E)$ & $(\mathrm{F})=\left((\mathrm{B})^{*}(\mathrm{D})\right) /\left((\mathrm{C})^{*}(\mathrm{E})\right)$ & (G) & $(H)=(F)^{*}(G)$ \\
\hline & 1 & Motorcycle & 10 & 28 & 2.41 & 1 & 0.86 & 20 & 17.214 \\
\hline & 2 & Car & 10 & 9.8 & 2.41 & 1 & 2.46 & 20 & 49.184 \\
\hline \multirow{5}{*}{ CO } & \multirow[b]{2}{*}{$\begin{array}{l}\text { Number } \\
\text { of trips }\end{array}$} & \multirow[b]{2}{*}{$\begin{array}{l}\text { Modes of } \\
\text { transport }\end{array}$} & \multirow[b]{2}{*}{$\begin{array}{l}\text { Distance } \\
(\mathrm{km})\end{array}$} & \multirow{2}{*}{$\begin{array}{l}\text { Energy } \\
\text { conversion } \\
\text { (km/liter) }\end{array}$} & \multirow[t]{2}{*}{ Emissions factor } & \multirow{2}{*}{$\begin{array}{l}\text { Number } \\
\text { of people } \\
\text { traveling } \\
\text { together }\end{array}$} & \multirow[t]{2}{*}{ Emissions per person } & \multirow{2}{*}{$\begin{array}{l}\text { Number of } \\
\text { trips per } \\
\text { month }\end{array}$} & \multirow[t]{2}{*}{ Emissions per person } \\
\hline & & & & & & & & & \\
\hline & & (A) & (B) & (C) & (D) & $(E)$ & $(\mathrm{F})=\left((\mathrm{B})^{*}(\mathrm{D})\right) /(\mathrm{E})$ & $(G)$ & $(H)=(F)^{*}(G)$ \\
\hline & 1 & Motorcycle & 10 & 28 & 0.014 & 1 & 0.14 & 20 & 2.800 \\
\hline & 2 & Car & 10 & 9.8 & 0.04 & 1 & 0.4 & 20 & 8.000 \\
\hline \multirow{5}{*}{$\mathrm{NO}_{\mathrm{x}}$} & \multirow[b]{2}{*}{$\begin{array}{l}\text { Number } \\
\text { of trips }\end{array}$} & \multirow[b]{2}{*}{$\begin{array}{l}\text { Modes of } \\
\text { transport }\end{array}$} & \multirow[b]{2}{*}{$\begin{array}{l}\text { Distance } \\
(\mathrm{km})\end{array}$} & \multirow{2}{*}{$\begin{array}{l}\text { Energy } \\
\text { conversion } \\
\text { (km/liter) }\end{array}$} & Emissions factor & \multirow{2}{*}{$\begin{array}{l}\text { Number } \\
\text { of people } \\
\text { traveling } \\
\text { together }\end{array}$} & Emissions per person & \multirow{2}{*}{$\begin{array}{l}\text { Number of } \\
\text { trips per } \\
\text { month }\end{array}$} & \multirow{2}{*}{\begin{tabular}{|l} 
Emissions per person \\
$\mathrm{kgNO}_{\mathrm{x}} /$ month/person
\end{tabular}} \\
\hline & & & & & $\mathrm{NO}_{\mathrm{x}}(\mathrm{kgNO} \times \mathrm{x} / \mathrm{km})$ & & $\mathrm{kgNO}_{\mathrm{x}} /$ trip/person & & \\
\hline & & (A) & (B) & (C) & (D) & $(E)$ & $(\mathrm{F})=\left((\mathrm{B})^{*}(\mathrm{D})\right) /(\mathrm{E})$ & (G) & $(H)=(F)^{*}(G)$ \\
\hline & 1 & Motorcycle & 10 & 28 & 0.00029 & 1 & 0.0029 & 20 & 0.058 \\
\hline & 2 & Car & 10 & 9.8 & 0.0020 & 1 & 0.02 & 20 & 0.400 \\
\hline \multirow{5}{*}{$\mathrm{SO}_{2}$} & \multirow[b]{2}{*}{$\begin{array}{l}\text { Number } \\
\text { of trips }\end{array}$} & & & Enerav & Emissions factor & \multirow{2}{*}{$\begin{array}{l}\text { Number } \\
\text { of people } \\
\text { traveling } \\
\text { together }\end{array}$} & Emissions per person & \multirow{2}{*}{$\begin{array}{l}\text { Number of } \\
\text { trips per } \\
\text { month }\end{array}$} & Emissions per person \\
\hline & & $\begin{array}{l}\text { Modes of } \\
\text { transport }\end{array}$ & $\begin{array}{l}\text { Distance } \\
(\mathrm{km})\end{array}$ & $\begin{array}{l}\text { conversion } \\
\text { (km/liter) }\end{array}$ & $\mathrm{SO}_{2}\left(\mathrm{kgSO}_{2} / \mathrm{km}\right)$ & & $\mathrm{kgSO}_{2} /$ trip/person & & $\mathrm{kgSO}_{2} / \mathrm{month} /$ person \\
\hline & & (A) & (B) & (C) & (D) & $(E)$ & $(\mathrm{F})=\left((\mathrm{B})^{*}(\mathrm{D})\right) /(\mathrm{E})$ & (G) & $(H)=(F)^{*}(G)$ \\
\hline & 1 & Motorcycle & 10 & 28 & 0.000008 & 1 & 0.000026 & 20 & 0.002 \\
\hline & 2 & Car & 10 & 9.8 & 0.000026 & 1 & 0.00026 & 20 & 0.005 \\
\hline & & & & & Emissions factor & Number & Emissions per person & & Emissions per person \\
\hline & $\begin{array}{l}\text { Number } \\
\text { of trips }\end{array}$ & $\begin{array}{l}\text { Modes of } \\
\text { transport }\end{array}$ & $\begin{array}{l}\text { Distance } \\
(\mathrm{km})\end{array}$ & $\begin{array}{l}\text { conversion } \\
\text { (km/liter) }\end{array}$ & $\begin{array}{l}\mathrm{PM}_{2.5}\left(\mathrm{kgPM}_{2.5} /\right. \\
\mathrm{km})\end{array}$ & $\begin{array}{l}\text { of people } \\
\text { traveling } \\
\text { together }\end{array}$ & $\mathrm{kgPM}_{2.5} /$ trip/person & $\begin{array}{l}\text { trips per } \\
\text { month }\end{array}$ & $\mathrm{kgPM}_{2.5} /$ month/person \\
\hline $\mathrm{PM}_{2.5}$ & & (A) & (B) & (C) & (D) & $(E)$ & $(\mathrm{F})=\left((\mathrm{B})^{*}(\mathrm{D})\right) /(\mathrm{E})$ & (G) & $(H)=(F)^{*}(G)$ \\
\hline & 1 & Motorcycle & 10 & 28 & 0.000032 & 1 & 0.00032 & 20 & 0.006 \\
\hline & 2 & Car & 10 & 9.8 & 0.00005 & 1 & 0.0005 & 20 & 0.010 \\
\hline
\end{tabular}


Table A2 | Case 2: Combination of Private Car and Commuter Line (Electricity-Based Train)

\begin{tabular}{|c|c|c|c|c|c|c|c|c|c|}
\hline \multirow{3}{*}{$\mathrm{CO}_{2}$} & \multirow[b]{2}{*}{$\begin{array}{l}\text { Number } \\
\text { of trips }\end{array}$} & \multirow[b]{2}{*}{$\begin{array}{l}\text { Modes of } \\
\text { transport }\end{array}$} & \multirow[b]{2}{*}{$\begin{array}{l}\text { Distance } \\
(\mathrm{km})\end{array}$} & \multirow{2}{*}{$\begin{array}{l}\text { Energy } \\
\text { conversion } \\
(\mathrm{km} / \mathrm{liter}) \\
\text { or }(\mathrm{km} / \\
\mathrm{kWh})\end{array}$} & Emissions factor & \multirow{2}{*}{$\begin{array}{l}\text { Number } \\
\text { of people } \\
\text { traveling } \\
\text { together }\end{array}$} & Emissions per person & \multirow{2}{*}{$\begin{array}{l}\text { Number of } \\
\text { trips per } \\
\text { month }\end{array}$} & \multirow{2}{*}{$\begin{array}{l}\text { Emissions per person } \\
\mathrm{kgCO}_{2} / \text { month/person }\end{array}$} \\
\hline & & & & & $\begin{array}{l}\mathrm{CO}_{2}\left(\mathrm{kgCO}_{2} / \mathrm{liter}\right) \\
\text { or }\left(\mathrm{kgCO}_{2} / \mathrm{kWh}\right)\end{array}$ & & $\mathrm{kgCO}_{2} /$ trip/person & & \\
\hline & & (A) & (B) & (C) & (D) & (E) & $(\mathrm{F})=\left((\mathrm{B})^{*}(\mathrm{D})\right) /\left((\mathrm{C})^{*}(\mathrm{E})\right)$ & (G) & $(H)=(F)^{*}(G)$ \\
\hline \multirow{8}{*}{ CO } & 1 & Car & 5 & 9.8 & 2.41 & 1 & 1.22959 & 20 & 24.592 \\
\hline & 2 & Train & 25 & 0.03252 & 0.774 & 1,400 & 0.42501 & 20 & 8.500 \\
\hline & \multirow[b]{2}{*}{$\begin{array}{l}\text { Number } \\
\text { of trips }\end{array}$} & \multirow[b]{2}{*}{$\begin{array}{l}\text { Modes of } \\
\text { transport }\end{array}$} & \multirow[b]{2}{*}{$\begin{array}{l}\text { Distance } \\
(\mathrm{km})\end{array}$} & \multirow{2}{*}{$\begin{array}{l}\text { Energy } \\
\text { conversion } \\
\text { (km/liter) } \\
\text { or (km/ } \\
\text { kWh) }\end{array}$} & Emissions factor & \multirow{2}{*}{$\begin{array}{l}\text { Number } \\
\text { of people } \\
\text { traveling } \\
\text { together }\end{array}$} & Emissions per person & \multirow[b]{2}{*}{$\begin{array}{l}\text { Number of } \\
\text { trips per } \\
\text { month }\end{array}$} & Emissions per person \\
\hline & & & & & $\begin{array}{l}\mathrm{CO}(\mathrm{kgCO} / \mathrm{km}) \text { or } \\
(\mathrm{kgCO} / \mathrm{kWh})\end{array}$ & & $\mathrm{kgCO} /$ trip/person & & $\mathrm{kgCO} / \mathrm{month} /$ person \\
\hline & \multirow{3}{*}{1} & (A) & (B) & (C) & (D) & $(\mathrm{E})$ & $(\mathrm{F})=\left((\mathrm{B})^{*}(\mathrm{D})\right) /(\mathrm{E})$ & (G) & $(H)=(F)^{*}(G)$ \\
\hline & & Car & 5 & 9.8 & 0.04 & 1 & 0.20000 & 20 & 4.000 \\
\hline & & (A) & (B) & (C) & (D) & $(E)$ & $(\mathrm{F})=\left((\mathrm{B})^{*}(\mathrm{D})\right) /\left((\mathrm{C})^{*}(\mathrm{E})\right)$ & $(G)$ & $(H)=(F)^{*}(G)$ \\
\hline & 2 & Train & 25 & 0.03252 & 0.0002 & 1,400 & 0.00011 & 20 & 0.002 \\
\hline \multirow{6}{*}{$\mathrm{NO}_{\mathrm{x}}$} & \multirow[b]{2}{*}{$\begin{array}{l}\text { Number } \\
\text { of trips }\end{array}$} & \multirow[b]{2}{*}{$\begin{array}{l}\text { Modes of } \\
\text { transport }\end{array}$} & \multirow[b]{2}{*}{$\begin{array}{l}\text { Distance } \\
(\mathrm{km})\end{array}$} & \multirow{2}{*}{$\begin{array}{l}\text { Energy } \\
\text { conversion } \\
(\mathrm{km} / \mathrm{liter}) \\
\text { or }(\mathrm{km} / \\
\mathrm{kWh})\end{array}$} & Emissions factor & \multirow[b]{2}{*}{$\begin{array}{l}\text { Number } \\
\text { of people } \\
\text { traveling } \\
\text { together }\end{array}$} & Emissions per person & \multirow[b]{2}{*}{$\begin{array}{l}\text { Number of } \\
\text { trips per } \\
\text { month }\end{array}$} & Emissions per person \\
\hline & & & & & $\begin{array}{l}\mathrm{NO}_{x}\left(\mathrm{kgNO}_{\mathrm{x}} / \mathrm{km}\right) \\
\text { or }\left(\mathrm{kgNO}_{x} / \mathrm{kWh}\right)\end{array}$ & & $\mathrm{kgNO}_{\mathrm{x}} /$ trip/person & & kgNOx/month/person \\
\hline & \multirow{3}{*}{1} & (A) & (B) & (C) & (D) & $(E)$ & $(\mathrm{F})=\left((\mathrm{B})^{*}(\mathrm{D})\right) /(\mathrm{E})$ & (G) & $(H)=(F)^{*}(G)$ \\
\hline & & Car & 5 & 9.8 & 0.002 & 1 & 0.01 & 20 & 0.200 \\
\hline & & $(A)$ & (B) & (C) & (D) & $(E)$ & $(\mathrm{F})=\left((\mathrm{B})^{*}(\mathrm{D})\right) /\left((\mathrm{C})^{*}(\mathrm{E})\right)$ & $(G)$ & $(H)=(F)^{*}(G)$ \\
\hline & 2 & Train & 25 & 0.03252 & 0.0052 & 1,400 & 0.00286 & 20 & 0.057 \\
\hline \multirow{6}{*}{$\mathrm{SO}_{2}$} & \multirow[b]{2}{*}{$\begin{array}{l}\text { Number } \\
\text { of trips }\end{array}$} & \multirow[b]{2}{*}{$\begin{array}{l}\text { Modes of } \\
\text { transport }\end{array}$} & \multirow[b]{2}{*}{$\begin{array}{l}\text { Distance } \\
(\mathrm{km})\end{array}$} & \multirow{2}{*}{$\begin{array}{l}\text { Energy } \\
\text { conversion } \\
(\mathrm{km} / \mathrm{liter}) \\
\text { or }(\mathrm{km} / \\
\mathrm{kWh})\end{array}$} & Emissions factor & \multirow[b]{2}{*}{$\begin{array}{l}\text { Number } \\
\text { of people } \\
\text { traveling } \\
\text { together }\end{array}$} & Emissions per person & & Emissions per person \\
\hline & & & & & $\begin{array}{l}\mathrm{SO}_{2}\left(\mathrm{kgSO}_{2} / \mathrm{km}\right) \\
\text { or }\left(\mathrm{kgSO}_{2} / \mathrm{kWh}\right)\end{array}$ & & $\mathrm{kgSO}_{2} /$ trip/person & $\begin{array}{l}\text { Number of } \\
\text { trips per } \\
\text { month }\end{array}$ & $\mathrm{kgSO}_{2} /$ month/person \\
\hline & & (A) & (B) & (C) & (D) & $(E)$ & $(\mathrm{F})=\left((\mathrm{B})^{*}(\mathrm{D})\right) /(\mathrm{E})$ & $(G)$ & $(H)=(F)^{*}(G)$ \\
\hline & 1 & Car & 5 & 9.8 & 0.000026 & 1 & 0.00013 & 20 & 0.003 \\
\hline & & (A) & (B) & (C) & (D) & $(E)$ & $(\mathrm{F})=\left((\mathrm{B})^{*}(\mathrm{D})\right) /\left((\mathrm{C})^{*}(\mathrm{E})\right)$ & $(G)$ & $(H)=(F)^{*}(G)$ \\
\hline & 2 & Train & 25 & 0.03252 & 0.0139 & 1,400 & 0.00763 & 20 & 0.153 \\
\hline & & & & Energy & Emissions factor & & Emissions per person & & Emissions per person \\
\hline Pll & $\begin{array}{l}\text { Number } \\
\text { of trips }\end{array}$ & $\begin{array}{l}\text { Modes of } \\
\text { transport }\end{array}$ & $\begin{array}{l}\text { Distance } \\
(\mathrm{km})\end{array}$ & $\begin{array}{l}\text { conversion } \\
(\mathrm{km} / \mathrm{liter}) \\
\text { or }(\mathrm{km} / \\
\mathrm{kWh})\end{array}$ & $\begin{array}{l}\mathrm{PM}_{2.5}\left(\mathrm{kgPM}_{2.5} /\right. \\
\mathrm{km}) \text { or }\left(\mathrm{kgPM}_{2.5} /\right. \\
\mathrm{kWh})\end{array}$ & $\begin{array}{l}\text { Number } \\
\text { of people } \\
\text { traveling } \\
\text { together }\end{array}$ & kgPM2.5/trip/person & $\begin{array}{l}\text { Number of } \\
\text { trips per } \\
\text { month }\end{array}$ & $\mathrm{kgPM}_{2.5} /$ month/person \\
\hline & & (A) & (B) & (C) & (D) & $(E)$ & $(\mathrm{F})=\left((\mathrm{B})^{*}(\mathrm{D})\right) /(\mathrm{E})$ & (G) & $(H)=(F)^{*}(G)$ \\
\hline & 1 & Car & 5 & 9.8 & 0.00005 & 1 & 0.00025 & 20 & 0.005 \\
\hline & & (A) & (B) & (C) & (D) & $(E)$ & $(\mathrm{F})=\left((\mathrm{B})^{*}(\mathrm{D})\right) /\left((\mathrm{C})^{*}(\mathrm{E})\right)$ & $(G)$ & $(H)=(F)^{*}(G)$ \\
\hline & 2 & Train & 25 & 0.03252 & 0.000189 & 1,400 & 0.00010 & 20 & 0.002 \\
\hline
\end{tabular}


Table A3 | Case 3: Combination of Bus and Motorcycle

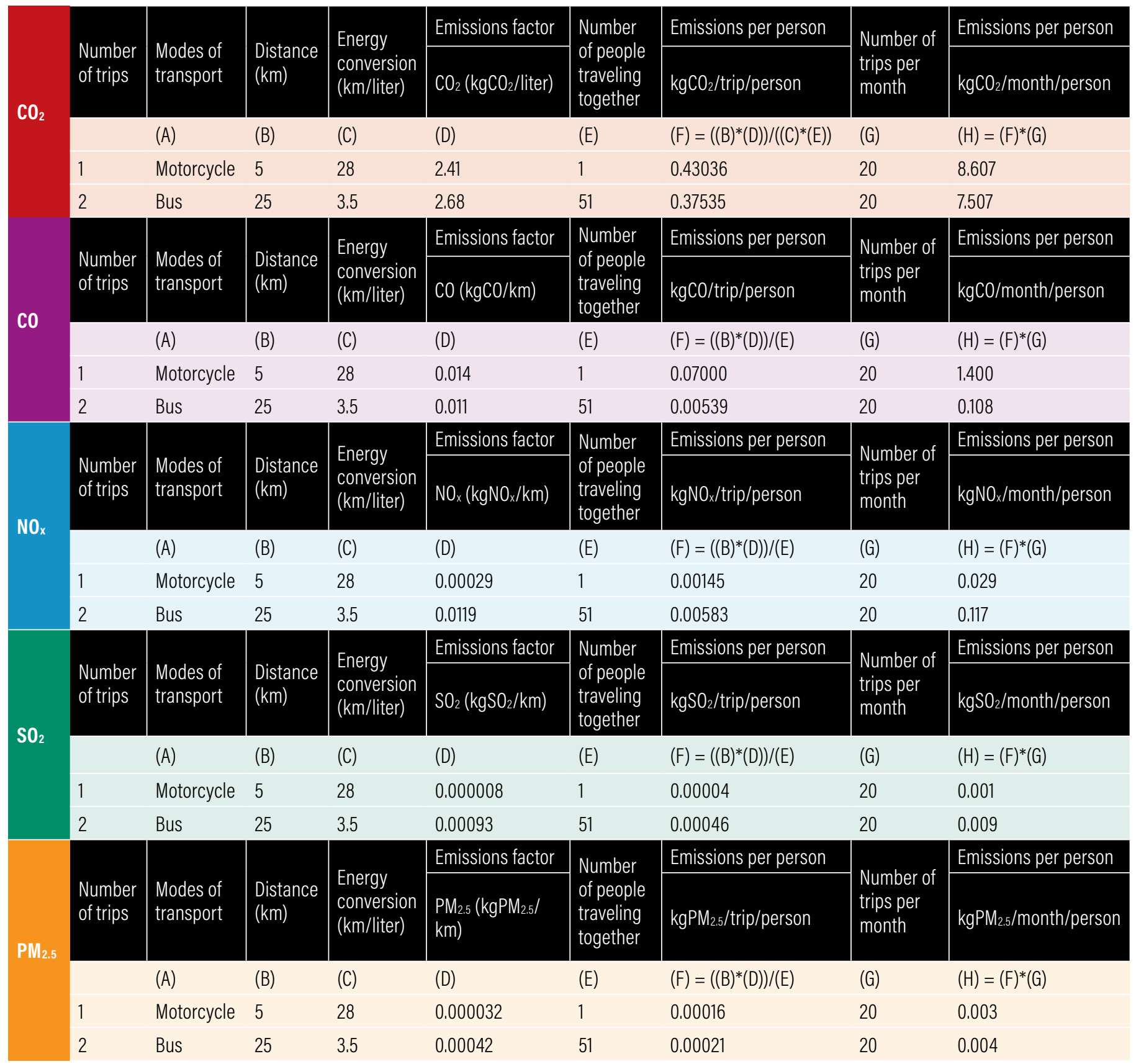

Notes: $\mathrm{CO}=$ carbon monoxide; $\mathrm{CO}_{2}=$ carbon dioxide; $\mathrm{kWh}=$ kilowatt-hour; $\mathrm{NO}=$ nitrogen oxides; $\mathrm{PM}_{2.5}=$ fine particulate matter; $\mathrm{SO}_{2}=$ sulfur dioxide. 


\section{APPENDIX B: SEQUESTERED $\mathrm{CO}_{2}$ CALCULATION DETAILS USING FIVE APPROACHES}

The tables below provide the calculation details for sequestered $\mathrm{CO}_{2}$ per tree, where

- $\mathrm{DBH}=$ diameter at the breast height measured in $\mathrm{cm}$;

- TTB = total tree biomass, calculated in kg using tree allometric equations;

- $\mathrm{AGB}=$ aboveground biomass, calculated in kg using tree allometric equations;

- $\mathrm{BGB}=$ below ground biomass, calculated in $\mathrm{kg}$ using tree allometric equations;

- carbon stock = the total sequestered carbon estimation, converted from TTB;

- $\mathrm{CO}_{2} \mathrm{e}=$ the total sequestered $\mathrm{CO}_{2}$ estimation, converted from carbon stock; and

- annual $\mathrm{CO}_{2} \mathrm{e}=$ total sequestered $\mathrm{CO}_{2}$ estimation annually.

Table B1 | Approach 1: Estimated Sequestered $\mathrm{CO}_{2}$ for Avicennia marina (White Mangrove) Planted in a Mangrove Forest

\begin{tabular}{|c|c|c|c|c|c|}
\hline Year & DBH (cm) & TTB (kg) & Carbon Stock (kg) & $\mathrm{CO}_{2} \mathrm{e}(\mathrm{kg})$ & Annual $\mathrm{CO}_{2} \mathrm{e}(\mathrm{kg})$ \\
\hline 2020 & 0.000 & 0.000 & 0.000 & 0.000 & 0.000 \\
\hline 2021 & 0.500 & 0.061 & 0.029 & 0.105 & 0.105 \\
\hline 2022 & 1.000 & 0.291 & 0.137 & 0.502 & 0.397 \\
\hline 2023 & 1.500 & 0.728 & 0.342 & 1.254 & 0.752 \\
\hline 2024 & 2.000 & 1.394 & 0.655 & 2.402 & 1.148 \\
\hline 2025 & 2.500 & 2.308 & 1.085 & 3.978 & 1.576 \\
\hline 2026 & 3.000 & 3.485 & 1.638 & 6.006 & 2.028 \\
\hline 2027 & 3.500 & 4.937 & 2.321 & 8.509 & 2.503 \\
\hline 2028 & 4.000 & 6.676 & 3.138 & 11.507 & 2.998 \\
\hline 2029 & 4.500 & 8.713 & 4.095 & 15.016 & 3.509 \\
\hline 2030 & 5.000 & 11.055 & 5.196 & 19.053 & 4.037 \\
\hline 2031 & 5.500 & 13.712 & 6.445 & 23.633 & 4.580 \\
\hline 2032 & 6.000 & 16.692 & 7.845 & 28.769 & 5.136 \\
\hline 2033 & 6.500 & 20.002 & 9.401 & 34.474 & 5.705 \\
\hline 2034 & 7.000 & 23.649 & 11.115 & 40.759 & 6.285 \\
\hline 2035 & 7.500 & 27.640 & 12.991 & 47.637 & 6.878 \\
\hline 2036 & 8.000 & 31.980 & 15.031 & 55.117 & 7.480 \\
\hline 2037 & 8.500 & 36.676 & 17.238 & 63.210 & 8.093 \\
\hline 2038 & 9.000 & 41.733 & 19.615 & 71.927 & 8.716 \\
\hline 2039 & 9.500 & 47.157 & 22.164 & 81.275 & 9.348 \\
\hline 2040 & 10.000 & 52.953 & 24.888 & 91.264 & 9.989 \\
\hline
\end{tabular}


Table B2 | Approach 2: Estimated Sequestered $\mathrm{CO}_{2}$ for Pinus merkussi (Pine) Planted in Dryland Forest

\begin{tabular}{|c|c|c|c|c|c|}
\hline Year & DBH (cm) & TTB $(\mathrm{kg})$ & Carbon Stock (kg) & $\mathrm{CO}_{2} \mathrm{e}(\mathrm{kg})$ & Annual $\mathrm{CO}_{2} \mathrm{e}(\mathrm{kg})$ \\
\hline 2020 & 0.000 & 0.000 & 0.000 & 0.000 & 0.000 \\
\hline 2021 & 0.500 & 0.019 & 0.009 & 0.032 & 0.032 \\
\hline 2022 & 1.000 & 0.103 & 0.048 & 0.178 & 0.145 \\
\hline 2023 & 1.500 & 0.279 & 0.131 & 0.481 & 0.304 \\
\hline 2024 & 2.000 & 0.566 & 0.266 & 0.976 & 0.495 \\
\hline 2025 & 2.500 & 0.980 & 0.461 & 1.690 & 0.714 \\
\hline 2026 & 3.000 & 1.535 & 0.721 & 2.645 & 0.956 \\
\hline 2027 & 3.500 & 2.242 & 1.054 & 3.865 & 1.219 \\
\hline 2028 & 4.000 & 3.114 & 1.464 & 5.367 & 1.502 \\
\hline 2029 & 4.500 & 4.160 & 1.955 & 7.170 & 1.803 \\
\hline 2030 & 5.000 & 5.390 & 2.533 & 9.290 & 2.120 \\
\hline 2031 & 5.500 & 6.814 & 3.202 & 11.744 & 2.454 \\
\hline 2032 & 6.000 & 8.439 & 3.967 & 14.545 & 2.802 \\
\hline 2033 & 6.500 & 10.275 & 4.829 & 17.709 & 3.164 \\
\hline 2034 & 7.000 & 12.329 & 5.795 & 21.249 & 3.540 \\
\hline 2035 & 7.500 & 14.609 & 6.866 & 25.178 & 3.929 \\
\hline 2036 & 8.000 & 17.121 & 8.047 & 29.508 & 4.330 \\
\hline 2037 & 8.500 & 19.874 & 9.341 & 34.252 & 4.744 \\
\hline 2038 & 9.000 & 22.873 & 10.750 & 39.421 & 5.169 \\
\hline 2039 & 9.500 & 26.125 & 12.279 & 45.027 & 5.605 \\
\hline 2040 & 10.000 & 29.637 & 13.929 & 51.079 & 6.053 \\
\hline
\end{tabular}


Table B3 | Approach 3: Estimated Sequestered $\mathrm{CO}_{2}$ for Eusideroxylon zwageri (Ulin) Planted in Dryland Forest

\begin{tabular}{|c|c|c|c|c|c|c|c|c|}
\hline Year & $\mathrm{DBH}(\mathrm{cm})$ & Volume $\left(\mathrm{m}^{3}\right)$ & AGB (kg) & BGB (kg) & TTB (kg) & Carbon Stock (kg) & $\mathrm{CO}_{2} \mathrm{e}(\mathrm{kg})$ & Annual $\mathrm{CO}_{2} \mathrm{e}(\mathrm{kg})$ \\
\hline 2020 & 0.000 & 0.000 & 0.000 & 0.000 & 0.000 & 0.000 & 0.000 & 0.000 \\
\hline 2021 & 0.500 & 0.000 & 0.023 & 0.006 & 0.030 & 0.016 & 0.060 & 0.060 \\
\hline 2022 & 1.000 & 0.000 & 0.138 & 0.037 & 0.175 & 0.096 & 0.353 & 0.293 \\
\hline 2023 & 1.500 & 0.000 & 0.399 & 0.108 & 0.506 & 0.278 & 1.021 & 0.668 \\
\hline 2024 & 2.000 & 0.001 & 0.847 & 0.229 & 1.075 & 0.591 & 2.169 & 1.148 \\
\hline 2025 & 2.500 & 0.001 & 1.519 & 0.410 & 1.929 & 1.061 & 3.891 & 1.722 \\
\hline 2026 & 3.000 & 0.002 & 2.449 & 0.661 & 3.110 & 1.710 & 6.272 & 2.381 \\
\hline 2027 & 3.500 & 0.003 & 3.667 & 0.990 & 4.657 & 2.561 & 9.392 & 3.120 \\
\hline 2028 & 4.000 & 0.004 & 5.202 & 1.404 & 6.606 & 3.633 & 13.324 & 3.932 \\
\hline 2029 & 4.500 & 0.005 & 7.081 & 1.912 & 8.993 & 4.946 & 18.138 & 4.814 \\
\hline 2030 & 5.000 & 0.007 & 9.332 & 2.520 & 11.851 & 6.518 & 23.902 & 5.764 \\
\hline 2031 & 5.500 & 0.009 & 11.977 & 3.234 & 15.211 & 8.366 & 30.679 & 6.777 \\
\hline 2032 & 6.000 & 0.011 & 15.043 & 4.062 & 19.105 & 10.508 & 38.531 & 7.852 \\
\hline 2033 & 6.500 & 0.014 & 18.551 & 5.009 & 23.560 & 12.958 & 47.517 & 8.986 \\
\hline 2034 & 7.000 & 0.017 & 22.525 & 6.082 & 28.607 & 15.734 & 57.696 & 10.178 \\
\hline 2035 & 7.500 & 0.020 & 26.986 & 7.286 & 34.272 & 18.850 & 69.122 & 11.426 \\
\hline 2036 & 8.000 & 0.023 & 31.956 & 8.628 & 40.584 & 22.321 & 81.851 & 12.729 \\
\hline 2037 & 8.500 & 0.027 & 37.454 & 10.113 & 47.567 & 26.162 & 95.936 & 14.085 \\
\hline 2038 & 9.000 & 0.032 & 43.503 & 11.746 & 55.249 & 30.387 & 111.428 & 15.492 \\
\hline 2039 & 9.500 & 0.037 & 50.120 & 13.532 & 63.653 & 35.009 & 128.378 & 16.950 \\
\hline 2040 & 10.000 & 0.042 & 57.327 & 15.478 & 72.805 & 40.043 & 146.836 & 18.458 \\
\hline \multicolumn{8}{|c|}{ Total $\mathrm{CO}_{2} \mathrm{e}$ at year $20(\mathrm{~kg})$} & 146.836 \\
\hline
\end{tabular}


Table B4 | Approach 4: Estimated Sequestered $\mathrm{CO}_{2}$ for Rhizopora apiculata (Mangrove) Planted in Peat Swamp Forest

\begin{tabular}{|c|c|c|c|c|c|c|c|c|}
\hline Year & DBH (cm) & Volume $\left(\mathrm{m}^{3}\right)$ & $A G B(k g)$ & BGB (kg) & TTB $(\mathrm{kg})$ & Carbon Stock (kg) & $\mathrm{CO}_{2} \mathrm{e}(\mathrm{kg})$ & Annual $\mathrm{CO}_{2} \mathrm{e}(\mathrm{kg})$ \\
\hline 2020 & 0.000 & 0.000 & 0.000 & 0.000 & 0.000 & 0.000 & 0.000 & 0.000 \\
\hline 2021 & 0.500 & 0.000 & 0.028 & 0.007 & 0.035 & 0.019 & 0.071 & 0.071 \\
\hline 2022 & 1.000 & 0.000 & 0.146 & 0.039 & 0.186 & 0.102 & 0.374 & 0.303 \\
\hline 2023 & 1.500 & 0.000 & 0.387 & 0.104 & 0.491 & 0.270 & 0.990 & 0.616 \\
\hline 2024 & 2.000 & 0.001 & 0.771 & 0.208 & 0.979 & 0.539 & 1.975 & 0.985 \\
\hline 2025 & 2.500 & 0.001 & 1.317 & 0.356 & 1.673 & 0.920 & 3.375 & 1.399 \\
\hline 2026 & 3.000 & 0.001 & 2.041 & 0.551 & 2.592 & 1.425 & 5.227 & 1.852 \\
\hline 2027 & 3.500 & 0.002 & 2.954 & 0.798 & 3.752 & 2.064 & 7.567 & 2.340 \\
\hline 2028 & 4.000 & 0.003 & 4.070 & 1.099 & 5.169 & 2.843 & 10.426 & 2.859 \\
\hline 2029 & 4.500 & 0.004 & 5.400 & 1.458 & 6.858 & 3.772 & 13.832 & 3.406 \\
\hline 2030 & 5.000 & 0.005 & 6.954 & 1.878 & 8.831 & 4.857 & 17.811 & 3.980 \\
\hline 2031 & 5.500 & 0.006 & 8.741 & 2.360 & 11.101 & 6.106 & 22.389 & 4.578 \\
\hline 2032 & 6.000 & 0.008 & 10.771 & 2.908 & 13.679 & 7.524 & 27,589 & 5.199 \\
\hline 2033 & 6.500 & 0.010 & 13.052 & 3.524 & 16.576 & 9.117 & 33.432 & 5.843 \\
\hline 2034 & 7.000 & 0.011 & 15.593 & 4.210 & 19.803 & 10.892 & 39.940 & 6.508 \\
\hline 2035 & 7.500 & 0.013 & 18.401 & 4.968 & 23.369 & 12.853 & 47.132 & 7.192 \\
\hline 2036 & 8.000 & 0.016 & 21.484 & 5.801 & 27.284 & 15.006 & 55.028 & 7.896 \\
\hline 2037 & 8.500 & 0.018 & 24.848 & 6.709 & 31.557 & 17.357 & 63.646 & 8.618 \\
\hline 2038 & 9.000 & 0.021 & 28.502 & 7.696 & 36.197 & 19.909 & 73.005 & 9.358 \\
\hline 2039 & 9.500 & 0.024 & 32.451 & 8.762 & 41.213 & 22.667 & 83.120 & 10.115 \\
\hline 2040 & 10.000 & 0.027 & 36.702 & 9.910 & 46.612 & 25.636 & 94.009 & 10.889 \\
\hline \multicolumn{8}{|c|}{ Total $\mathrm{CO}_{2} \mathrm{e}$ at year $20(\mathrm{~kg})$} & 94.009 \\
\hline
\end{tabular}


Table B5 | Approach 5: Estimated Sequestered $\mathrm{CO}_{2}$ for Artocarpus integer (Jackfruit Tree) Planted in Dryland Forest

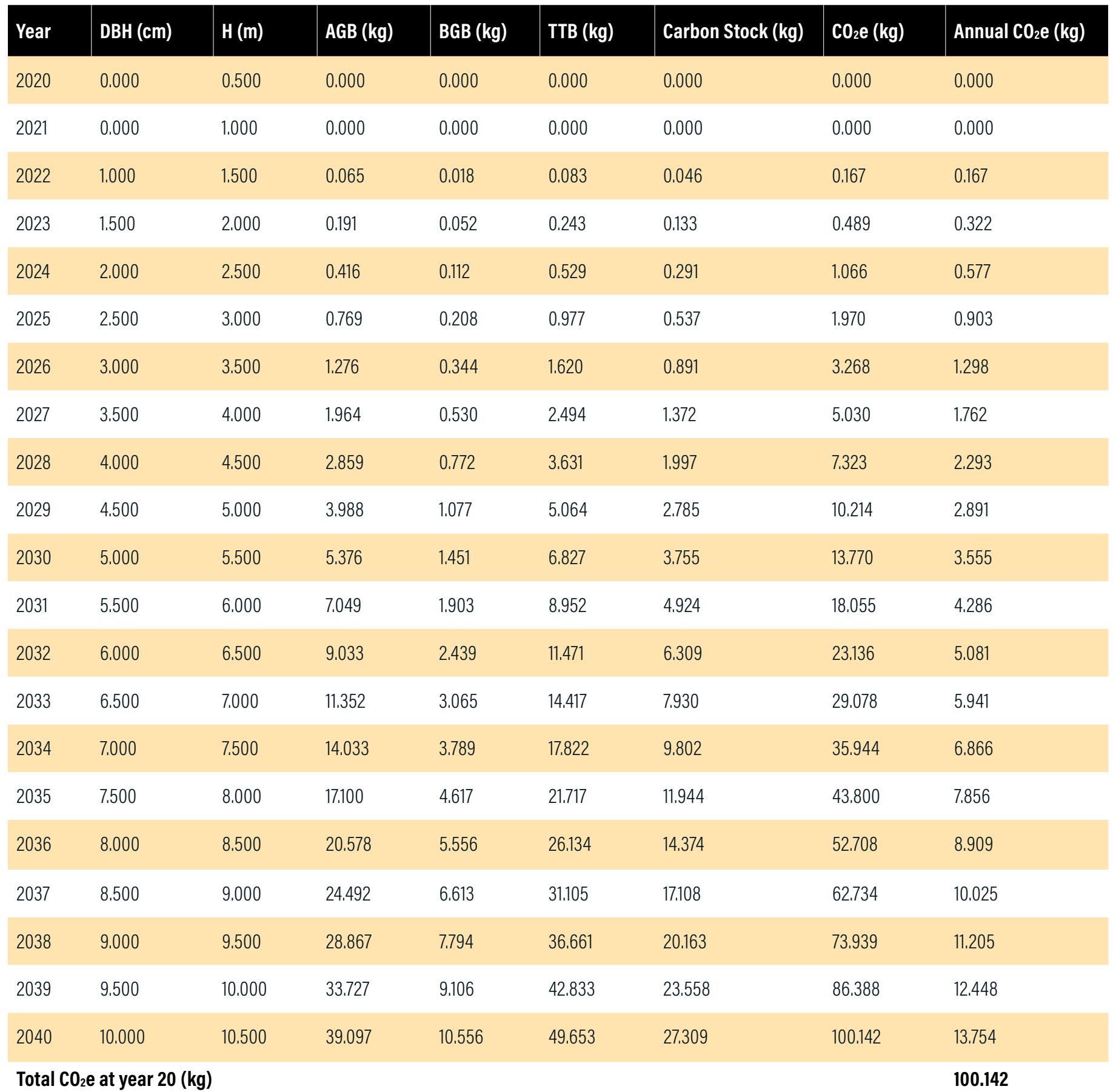




\section{APPENDIX C: NUMBER OF TREES CALCULATED FROM TOTAL EMISSIONS}

\section{PER PERSON}

The tables below provide three different travel cases to calculate the number of trees needed using five different tree species as examples (tree species in EMISI application are not limited to these five species). The tree species are varied based on the restoration needs, which are determined by several restoration and tree-planting organizations.

Table C1 | Case 1: Using Private Car or Motorcycle

\begin{tabular}{|c|c|c|c|}
\hline Total Emissions per Person (TEP $)(\mathrm{kg})$ & Tree Options & Estimated Sequestered $\mathrm{CO}_{2}(\mathrm{~kg})$ & Number of Trees \\
\hline (A) & (B) & (C) & $(D)=(A) /(C)$ \\
\hline 66.40 & Avicennia marina & 91.26 & 0.73 \\
\hline 66.40 & Pinus merkussi & 51.08 & 1.30 \\
\hline 66.40 & Eusideroxylon zwageri & 146.84 & 0.45 \\
\hline 66.40 & Rhizopora apiculata & 94.01 & 0.71 \\
\hline 66.40 & Artocarpus integer & 100.14 & 0.66 \\
\hline
\end{tabular}

Table C2 | Case 2: Combination of Private Car and Commuter Line (Electricity-Based Train)

\begin{tabular}{l|l|l|l|}
\hline Total Emissions per Person (TEP) $\mathbf{( k g )}$ & Tree Options & Estimated Sequestered $\mathbf{C O}_{\mathbf{2}}(\mathbf{k g})$ & Number of Trees \\
\hline (A) & (B) & (C) & $(\mathrm{D})=(\mathrm{A}) /(\mathrm{C})$ \\
\hline 33.09 & Avicennia marina & 91.26 & 0.36 \\
\hline 33.09 & Pinus merkussi & 51.08 & 0.65 \\
\hline 33.09 & Eusideroxylon zwageri & 146.84 & 0.23 \\
\hline 33.09 & Rhizopora apiculata & 94.01 & 0.35 \\
\hline 33.09 & Artocarpus integer & 100.14 & 0.33
\end{tabular}

Table C3 | Case 3: Combination of Bus and Motorcycle

\begin{tabular}{|l|l|l|l|}
\hline Total Emissions per Person $\left(\right.$ TEP $\left._{\mathrm{p}}\right)(\mathbf{k g})$ & Tree Options & Estimated Sequestered $\mathbf{C O}_{\mathbf{2}}(\mathbf{k g})$ & Number of Trees \\
\hline (A) & (B) & (C) & $(\mathrm{D})=(\mathrm{A}) /(\mathrm{C})$ \\
\hline 15.36 & Avicennia marina & 91.26 & 0.17 \\
\hline 15.36 & Pinus merkussi & 51.08 & 0.30 \\
\hline 15.36 & Eusideroxylon zwageri & 146.84 & 0.10 \\
\hline 15.36 & Rhizopora apiculata & 94.01 & 0.16 \\
\hline 15.36 & Artocarpus integer & 100.14 & 0.15 \\
\hline
\end{tabular}




\section{ABBREVIATIONS}

AGB Aboveground Biomass

BEF Biomass Expansion Factor

BGB Belowground Biomass

CDM Clean Development Mechanism

co Carbon Monoxide

$\mathrm{CO}_{2}$ Carbon Dioxide

D Diameter

DBH Diameter at the Breast Height

EF Emissions Factor

EMISI Indonesia Zero Emissions Application

ESC Estimated Sequestered Carbon Dioxide

f Function

GHG Greenhouse Gas

H Height

IPCC Intergovernmental Panel on Climate Change

MoEF Ministry of Environment and Forestry

NOx Nitrogen Oxides

$\mathbf{P M}_{2.5} \quad$ Fine Particulate Matter

Rt Roots

$\mathrm{SO}_{2} \quad$ Sulfur Dioxide

TCF Tree Carbon Fraction

TEP $_{\mathrm{p}}$ Total Emissions Per Person

TTB Total Tree Biomass

WD Wood Density 


\section{REFERENCES}

Aalde, H., P. Gonzalez, M. Gytarsky, T. Krug, W.A. Kurz, S. Ogle, J. Raison, et al. 2006. "Forest Land." In Agriculture, Forestry and Other Land Use. Vol. 4 of 2006 IPCC Guidelines for National Greenhouse Gas Inventories, edited by S. Eggleston, L. Buendia, K. Miwa, T. Ngara, and K. Tanabe. Geneva: Intergovernmental Panel on Climate Change. https://www.ipcc-nggip. iges.or.jp/public/2006gl/pdf/4_Volume4/V4_04_Ch4_Forest_Land.pdf.

ADB (Asian Development Bank). 2017. Guidelines for Estimating Greenhouse Gas Emissions of ADB Projects. Mandaluyong, Philippines: ADB. http://dx.doi.org/10.22617/TIM178659-2.

Amalia, M., B.P. Resosudarmo, and J. Bennett. 2013. "The Consequences of Urban Air Pollution for Child Health: What Does Self-Reporting Data in the Jakarta Metropolitan Area Reveal?" Working Paper 2013/09. Canberra, Australia: Arndt-Corden Department of Economics, Crawford School of Public Policy, Australian National University College of Asia and the Pacific. https://crawford.anu.edu.au/acde/publications/publish/papers/ wp2013/wp_econ_2013_09.pdf.

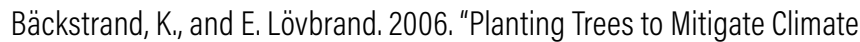
Change: Contested Discourses of Ecological Modernization, Green Governmentality and Civic Environmentalism." Global Environmental Politics 6 (1): 50-75. https://doi.org/10.1162/glep.2006.6.1.50.

Badach, J., M. Dymnicka, and A. Baranowski. 2020. "Urban Vegetation in Air Quality Management: A Review and Policy Framework." Sustainability 12 (3): 1258. https://doi.org/10.3390/su12031258.

Basuki, I. J.B. Kauffman, J. Peterson, G. Anshari, and D. Murdiyarso, 2019. "Land Cover Changes Reduce Net Primary Production in Tropical Coastal Peatlands of West Kalimantan, Indonesia." Mitigation and Adaptation Strategies for Global Change 24 (April): 557-73. https://doi.org/10.1007/ s11027-018-9811-2.

Bernal, B., L.T. Murray, and T.R.H. Pearson. 2018. "Global Carbon Dioxide Removal Rates from Forest Landscape Restoration Activities." Carbon Balance and Management 13 (November). https://doi.org/10.1186/s13021018-0110-8.

Boedisantoso, R., T.N. Ciptaningayu, A.D. Syafei, A.F. Assomadi, A. Slamet, and J. Hermana. 2019. "Reduction of $\mathrm{CO}, \mathrm{NO}_{x}$ and $\mathrm{SO}_{2}$ Emissions from the Transfer of Private Vehicles to Public Transportation: A Case Study of Surabaya." IOP Conference Series: Earth and Environmental Science 239 (February): 012041. https://doi.org/10.1088/1755-1315/239/1/012041.

Brander, M., A. Sood, C. Wylie, A. Haughton, and J. Lovell. 2011. "ElectricitySpecific Emission Factors for Grid Electricity." Technical Paper. Edinburgh, UK: Ecometrica. https://ecometrica.com/assets/Electricity-specificemission-factors-for-grid-electricity.pdf.
Buis, A. 2019. "Examining the Viability of Planting Trees to Help Mitigate Climate Change." NASA Global Climate Change: Vital Signs of the Planet, November 7. https://climate.nasa.gov/news/2927/examining-the-viabilityof-planting-trees-to-help-mitigate-climate-change.

Bustomi, S., R. Imanuddin, and N. Mindawati. 2009. "Model pertumbuhan diameter dan tinggi pohon lima jenis Dipterocarpaceae di hutan penelitian Carita-Banten." Jurnal Penelitian Hutan Tanaman 6 (1): 19-28. https://doi. org/10.20886/jpht.2009.6.1.19-28.

Carrington, D. 2019. "Tree Planting 'Has Mind-Blowing Potential' to Tackle Climate Crisis." The Guardian, July 4. https://www.theguardian.com/ environment/2019/jul/04/planting-billions-trees-best-tackle-climate-crisisscientists-canopy-emissions

Cervero, R. 1991. "Paratransit in Southeast Asia: A Market Response to Poor Roads?" Review of Urban \& Regional Development Studies 3 (1): 3-27. https://doi.org/10.1111/j.1467-940X.1991.tb00076.x.

Chave, J., M. Réjou-Méchain, A. Búrquez, E. Chidumayo, M.S. Colgan, W.B.C. Delitti, A. Duque, et al. 2014. "Improved Allometric Models to Estimate the Aboveground Biomass of Tropical Trees." Global Change Biology 20 (10): 3177-90. https://doi.org/10.1111/gcb.12629.

Coppolino, J. 2014. "How Planting Trees Can Help Reduce Your Carbon Footprint." One Tree Planted, May 25. https://onetreeplanted.org/blogs/ stories/planting-trees-reduce-carbon-footprint.

EECA (Energy Efficiency and Conservation Authority). 2019. " $\mathrm{CO}_{2}$ Emission Calculator," May 5. https://www.eecabusiness.govt.nz/tools/wood-energycalculators/co2-emission-calculator/.

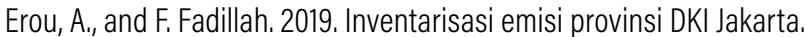
Information Sheet Series: Air Pollution 7. South Jakarta, Indonesia: Indonesian Center for Environmental Law. https://icel.or.id/wp-content/ uploads/Brief-Inventarisasi-emisi-udara-jakarta-OK.pdf.

Ghozali, K.I. 2018. "TransJakarta Tambah 300 Unit Bus Low Entry." detikOto, February 13. https://oto.detik.com/berita/d-3865572/transjakarta-tambah300-unit-bus-low-entry.

Gorte, R.W. 2009. U.S. Tree Planting for Carbon Sequestration. Congressional Research Service Report 7-5700. Washington, DC: Congressional Research Service. https://fas.org/sgp/crs/misc/R40562.pdf.

Graham, V., S.G. Laurance, A. Grech, A. McGregor, and 0. Venter. 2016. "A Comparative Assessment of the Financial Costs and Carbon Benefits of REDD+ Strategies in Southeast Asia." Environmental Research Letters 11 (11): 114022. https://doi.org/10.1088/1748-9326/11/11/114022. 
Graham, V., S.G. Laurance, A. Grech, and 0. Venter. 2017. "Spatially Explicit Estimates of Forest Carbon Emissions, Mitigation Costs and REDD+ Opportunities in Indonesia." Environmental Research Letters 12 (4): 044017. https://doi.org/10.1088/1748-9326/aa6656.

Hasan, M.H., W.K. Muzammil, T.M.I. Mahlia, A. Jannifar, and I. Hasanuddin. 2012. "A Review on the Pattern of Electricity Generation and Emission in Indonesia from 1987 to 2009." Renewable and Sustainable Energy Reviews 16 (5): 3206-19. https://doi.org/10.1016/j.rser.2012.01.075.

Hergoualc'h, K, and L.V. Verchot. 2011. "Stocks and Fluxes of Carbon Associated with Land Use Change in Southeast Asian Tropical Peatlands: A Review." Global Biogeochemical Cycles 25 (2). https://doi. org/10.1029/2009GB003718.

Hilman, 0., and F. Harvey. 2019. "US Is Hotbed of Climate Change Denial, Major Global Survey Finds." The Guardian, May 8. https://www. theguardian.com/environment/2019/may/07/us-hotbed-climate-changedenial-international-poll.

ICA0 (International Civil Aviation Organization). 2016. "ICA0 Carbon Emissions Calculator." https://www.icao.int/environmental-protection/ Carbonoffset/Pages/default.aspx.

IPCC (Intergovernmental Panel on Climate Change). 2006. 2006 IPCC Guidelines for National Greenhouse Gas Inventories. Edited by S. Eggleston, L. Buendia, K. Miwa, T. Ngara, and K. Tanabe. Geneva: IPCC. https://www.ipcc-nggip.iges.or.jp/public/2006gl/.

Jaenicke, H. 1999. Good Tree Nursery Practices: Practical Guidelines for Research Nurseries. Edited by B. Hince. Nairobi: International Centre for Research in Agroforestry. http://apps.worldagroforestry.org/Units/Library/ Books/PDFs/17_Good_tree_nursery_practices.pdf? $\mathrm{n}=44$.

Janhäll, S. 2015. "Review on Urban Vegetation and Particle Air PollutionDeposition and Dispersion." Atmospheric Environment 105 (March): 130-37. https://doi.org/10.1016/j.atmosenv.2015.01.052.

Joewono, T.B., and H. Kubota. 2007. "User Satisfaction with Paratransit in Competition with Motorization in Indonesia: Anticipation of Future Implications." Transportation 34 (May): 337-54. https://doi.org/10.1007/ s11116-007-9119-7.

Jung, J., and Y. Koo. 2018. "Analyzing the Effects of Car Sharing Services on the Reduction of Greenhouse Gas (GHG) Emissions." Sustainability 10 (2): 539. https://doi.org/10.3390/su10020539.

Kirby, K. R., and C. Potvin. 2007. "Variation in Carbon Storage among Tree Species: Implications for the Management of a Small-Scale Carbon Sink Project." Forest Ecology and Management 246 (2-3): 208-21. https://doi. org/10.1016/j.foreco.2007.03.072.
Krisnawati, H., W.C. Adinugroho, and R. Imanuddin. 2012. Allometric Models for Estimating Tree Biomass at Various Forest Ecosystem Types in Indonesia. Bogor, Indonesia: Research and Development Center for Conservation and Rehabilitation, Forestry Research and Development Agency, Ministry of Forestry. https://www.researchgate. net/publication/257068887_Allometric_Models_for_Estimating_Tree_ Biomass_at_Various_Forest_Ecosystem_Types_in_Indonesia_Engl_ version.

Kusmana, C., T. Hidayat, T. Tiryana, 0. Rusdiana, and Istomo. 2018. "Allometric Models for Above- and Below-Ground Biomass of Sonneratia Spp." Global Ecology and Conservation 15 (July): e00417. https://doi. org/10.1016/j.gecco.2018.e00417.

Manuri, S., C. Brack, F. Noor'an, T. Rusolono, S.M. Anggraini, H. Dotzauer, and I. Kumara. 2016. "Improved Allometric Equations for Tree Aboveground Biomass Estimation in Tropical Dipterocarp Forests of Kalimantan, Indonesia." Forest Ecosystems 3 (1): 28. https://doi.org/10.1186/s40663-0160087-2.

MoEF (Ministry of Environment and Forestry). 2010. "Peraturan Menteri Negara Lingkungan Hidup nomor 12 tahun 2010." HukumOnline.com, March 25. https://m.hukumonline.com/pusatdata/detail//t4c283ee4c67c5/ node/It511a13750665b/peraturan-menteri-negara-lingkungan-hidup-no12-tahun-2010-pelaksanaan-pengendalian-pencemaran-udara-di-daerah.

MoEF. 2012. Metodologi Penghitungan Tingkat Emisi Gas Rumah Kaca Kegiatan Pengadaan dan Penggunaan Energi. Vol. 1 of Pedoman Penyelenggaraan Inventarisasi Gas Rumah Kaca Nasional Buku II. Jakarta: MoEF, Republic of Indonesia. https://kemenperin.go.id/download/6886.

MoEF. 2017. Peraturan Menteri Lingkungan Hidup No 73 Tahun 2017 tentang Pedoman Penyelenggaraan dan Pelaporan Inventarisasi Gas Rumah Kaca Nasional. Jakarta: MoEF, Republic of Indonesia. http://jdih. menlhk.co.id/uploads/files/P.73\%20(4).pdf.

MoEF. 2019. Statistik Tahun 2018: Direktorat Jenderal Pengendalian Perubahan Iklim. Jakarta: Directorate General of Climate Change Control, MoEF, Republic of Indonesia. http://ditjenppi.menlhk.go.id/reddplus/ images/adminppi/dokumen/statistik_PPI_2018_opt.pdf.

MoEMR (Ministry of Energy and Mineral Resources). 2017. Kajian Penggunaan Faktor Emisi Lokal (Tier 2) dalam Inventarisasi GRK Sektor Energi. Jakarta: MoEMR, Republic of Indonesia, https://www.esdm.go.id/ assets/media/content/content-kajian-emisi-gas-rumah-kaca-2017.pdf.

Paul, K.I, S.H. Roxburgh, J. Chave, J.R. England, A. Zerihun, A. Specht, T. Lewis, et al. 2016. "Testing the Generality of Above-Ground Biomass Allometry across Plant Functional Types at the Continent Scale." Global Change Biology 22 (6): 2106-24. https://doi.org/10.1111/gcb.13201. 
Rathi, A. 2020. "Why Planting a Trillion Trees Should Start with Small Farmers." Bloomberg Green, January 27. https://www.bloomberg.com/ news/articles/2020-01-27/why-planting-a-trillion-trees-should-start-withsmall-farmers,

Rexon, J., and A. Pearson. 2010. Clean Development Mechanism Project Design Document Form for Small-Scale Afforestation and Reforestation Project Activities (CDM-SSC-AR-PDD). Bonn, Germany: Clean Development Mechanism, United Nations Framework Convention on Climate Change.

Röhling, S., K. Dunger, G. Kändler, S. Klatt, T. Riedel, W. Stümer, and J. Brötz. 2016. "Comparison of Calculation Methods for Estimating Annual Carbon Stock Change in German Forests under Forest Management in the German Greenhouse Gas Inventory." Carbon Balance and Management 11 (June): 12. https://doi.org/10.1186/s13021-016-0053-x.

Rudi, A. 2015. "Agar Nyaman, Berapa Jumlah Ideal Penumpang di dalam Gerbong KRL?" Kompas.com, December 2. https://megapolitan.kompas. com/read/2015/12/02/15071151/Agar.Nyaman.Berapa.Jumlah.Ideal. Penumpang.di.dalam.Gerbong.KRL

SAS (Scandinavian Airlines System). 2019. "SAS to Offset the Flight Carbon Footprint of EuroBonus Members." January 31. https://www.sasgroup.net/ newsroom/press-releases/2019/sas-to-offset-the-flight-carbon-footprintof-eurobonus-members/.

Shrestha, R.M., N.T.K. Oanh, R.P.S. Shrestha, M. Rupakheti, S. Rajbhandari, D.A. Permadi, T. Kanabkaew, and M. Iyngararasan. 2013. Atmospheric Brown Clouds (ABC): Emission Inventory Manual. Nairobi: United Nations Environment Programme. https://wedocs.unep.org/bitstream/ handle/20.500.11822/21482/ABC_EIM.pdf?sequence=1\&isAllowed $=y$.

Siregar, C.A. 2007. "Pertumbuhan Anakan Mangrove pada Berabagai Kondisi Tapak Berpasir pasca Tsunami di Aceh." Jurnal Penelitian Hutan dan Konservasi Alam 4 (2): 169-81. https://doi.org/10.20886/ jphka.2007.4.2.169-181.

Song, S. 2017. Transport Emissions \& Social Cost Assessment: Methodology Guide. Washington, DC: World Resources Institute https://files.wri.org/s3fs-public/Transport_Emissions_Social_Cost_ Assessment_Methodology_Guide.pdf.
Suatmadi, A.Y, F. Creutzig, and I.M. Otto. 2019. "On-Demand Motorcycle Taxis Improve Mobility, Not Sustainability." Case Studies on Transport Policy 7 (2): 218-29. https://doi.org/10.1016/j.cstp.2019.04.005

UNFCCC (United Nations Framework Convention on Climate Change), 2019 , CDM Methodology Booklet. 11th ed. Bonn, Germany: UNFCCC. https://cdm. unfccc.int/methodologies/documentation/meth_booklet.pdf.

van Vuuren, D.P., M. Hoogwijk, T. Barker, K. Riahi, S. Boeters, J. Chateau, S. Scrieciu, et al. 2009. "Comparison of Top-Down and Bottom-Up Estimates of Sectoral and Regional Greenhouse Gas Emission Reduction Potentials." Energy Policy 37 (12): 5125-39. https://doi.org/10.1016/j.enpol.2009.07.024.

Wang, J., and H.A. Rakha. 2017. "Electric Train Energy Consumption Modeling." Applied Energy 193 (May): 346-55. https://doi.org/10.1016/j. apenergy.2017.02.058.

World Bank. 2019. "Augment, Connect, Target: Realizing Indonesia's Urban Potential." October 3. https://www.worldbank.org/en/country/indonesia/ publication/augment-connect-target-realizing-indonesias-urbanpotential.

Xylia, M., S. Leduc, A.-B. Laurent, P. Patrizio, Y. van der Meer, F. Kraxner, and S. Silveira. 2019. "Impact of Bus Electrification on Carbon Emissions: The Case of Stockholm." Journal of Cleaner Production 209 (February): 74-87. https://doi.org/10.1016/j.jclepro.2018.10.085.

Yuan, W., and H.C. Frey. 2020. "Potential for Metro Rail Energy Savings and Emissions Reduction via Eco-Driving." Applied Energy 268 (June): 114944. https://doi.org/10.1016/j.apenergy.2020.114944.

Zadek, H., and R. Schulz. 2010. "Methods for the Calculation of CO2 Emissions in Logistics Activities." In Advanced Manufacturing and Sustainable Logistics, edited by W. Dangelmaier, A. Blecken, R. Delius, and S. Klöpfer, 263-68. Lecture Notes in Business Information Processing, vol. 46. Berlin: Springer. https://doi.org/10.1007/978-3-642-12494-5_24. 


\section{ACKNOWLEDGMENTS}

We are pleased to acknowledge our various institutional strategic partners who provide core funding to the World Resources Institute (WRI). Their bilateral funding for projects made this publication possible.

The authors would like to thank the following people for providing invaluable insight and assistance in the development of this paper: Dean Affandi (WRI Indonesia), Sophie Atwood (WRI), Ines Ayostina (WRI Indonesia), Syamsul Budiman (Rimba Makmur Utama), Indira Darmoyono (Deutsche Gesellschaft für Internationale Zusammenarbeit), Dicky Edwin Hindarto (Joint Crediting Mechanism Indonesia), Tiza Mafira (Climate Policy Initiative), Amen Ra Mashariki (WRI), Dewi Mustika (WRI Indonesia), Nizar Nasrullah (Institut Pertanian Bogor), Kevin Powers (WRI), Janet Ranganathan (WRI), Ethan Roday (WRI), Ryan Sclar (WRI), Frances Seymour (WRI), Ahmad Shahab (WRI Indonesia), Emilia Suarez (WRI), Gregory Taff (WRI), La Ode Muhammad Abdul Wahid (Badan Pengkajian Penerapan Teknologi Indonesia), and Retno Wihanesta (WRI Indonesia).

We also thank our internal and external reviewers, Ramadhani Achdiawan (Collins Higgins Consulting), Puspita Dirgahayani (Institut Teknologi Bandung), David Gibbs (WRI), Yohanes Ginting (Alam Sehat Lestari), Arya Harsono (WRI), Puji Lestari (Institut Teknologi Bandung), Xiangyi Li (WRI), Dedy Mahardika (WRI Indonesia), Solichin Manuri (Daemeter), John-Rob Pool (WRI), Adi Pradana (WRI Indonesia), David Rich (WRI Indonesia), Su Song (WRI China), Nur Febriani Wardi (Alam Sehat Lestari), Arief Wijaya (WRI Indonesia), and Shengyin Xu (WRI).

The authors would also like to thank Reidinar Juliane, Romain Warnault, Lauri Scherer, Farhan Fahrezi, and Aulia Lastriarsi for their extensive support during the editing and design of this study. Opinions or points of view expressed in this report are those of the authors and do not necessarily reflect the position of the reviewers and our partners.

\section{ABOUT THE AUTHORS}

Muhamad Rizki is a Mobility and Transportation Specialist in WRI Indonesia's Emissions Project. Contact: muhamad.rizki@wri.org

Dewi Sari is a Sustainability Analyst in WRI Indonesia's Emissions Project. Contact: dewi.sari@wri.org

Nanda Noor is a Sustainable Land Use and Emissions Project Lead in WRI Indonesia. Contact: nanda.noor@wri.org

Imam Basuki, PhD, a Peatland Hydrology and Oil Palm Scientific Lead with Winrock International.

Rinaldi Imanuddin, MSc, is a Forest Assessment and Biometrics researcher at the Research, Development and Innovation Agency (FORDA), Ministry of Environment and Forestry of Indonesia.

Seny Damayanti, MT, is a Environmental Engineering Lecturer at the Faculty of Civil and Environmental Engineering, Institut Teknologi Bandung (ITB) in Indonesia.

Nadia Irwanto is a former Data Science and Technology Intern in WRI Indonesia.

\section{ABOUT WRI}

The World Resources Institute is a global research organization that turns big ideas into action at the nexus of environment, economic opportunity, and human well-being.

\section{Our Challenge}

Natural resources are at the foundation of economic opportunity and human well-being. But today, we are depleting Earth's resources at rates that are not sustainable, endangering economies and people's lives. People depend on clean water, fertile land, healthy forests, and a stable climate. Livable cities and clean energy are essential for a sustainable planet. We must address these urgent, global challenges this decade.

\section{Our Vision}

We envision an equitable and prosperous planet driven by the wise management of natural resources. We aspire to create a world where the actions of government, business, and communities combine to eliminate poverty and sustain the natural environment for all people.

\section{Our Approach}

COUNT IT

We start with data. We conduct independent research and draw on the latest technology to develop new insights and recommendations. Our rigorous analysis identifies risks, unveils opportunities, and informs smart strategies. We focus our efforts on influential and emerging economies where the future of sustainability will be determined.

\section{CHANGE IT}

We use our research to influence government policies, business strategies, and civil society action. We test projects with communities, companies, and government agencies to build a strong evidence base. Then, we work with partners to deliver change on the ground that alleviates poverty and strengthens society. We hold ourselves accountable to ensure our outcomes will be bold and enduring.

\section{SCALE IT}

We don't think small. Once tested, we work with partners to adopt and expand our efforts regionally and globally. We engage with decisionmakers to carry out our ideas and elevate our impact. We measure success through government and business actions that improve people's lives and sustain a healthy environment. 